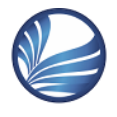

ELK

Asia Pacific Journals

www.elkjournals.com

\title{
EVALUATING THE IMPACT OF URBAN REFORMS BY COLONIZER ON SPATIAL STRUCTURES OF NEW INDIGENOUS COMMUNITIES: A CASE OF KRISHAN NAGAR, LAHORE
}

\begin{tabular}{|c|c|c|}
\hline Aneela Yaseen & Prof. Dr. Neelum Naz & Dr. Shama Anbrine \\
Lecturer & Chairperson & Assistant Professor \\
Department of Architecture & Department of Architecture & Department of Architecture \\
UOMSATS Institute of Information & UET, Lahore. & UET, Lahore. \\
Technology, Islamabad & neelumn@gmail.com & Shama.anbrine@ gmail.com \\
aneela.yaseen@ comsats.edu.pk. & & \\
\hline
\end{tabular}

\begin{abstract}
The 'white towns' of colonial cities with their tree lined avenues and palatial bungalows stood in stark contrast to the 'native towns' with narrow meandering streets and compact multistoried houses. Lahore, a city annexed by the British in 1849, was no exception. Hence the new indigenous communities (NICs) developed at the turn of twentieth century show a significant deviation from the traditional native town. One significant example is Krishan Nagar; a town developed in the 1930s by the wealthy Hindu merchants of the city. This paper provides insight about the spatial structures of the NICs using Krishan Nagar as the primary case study. The key argument include how the street life and sociocultural values of natives were influenced by urban reforms. How much of these urban changes by colonizer were accepted and how much was negotiated by natives. By doing so, this paper aims to reveal the impact of Western urban ideals by investigating the layout pattern (from organic to rectilinear), streetscape (from picturesque to negotiated), public realm (from sovereign to constrained) and socio-cultural dimensions (from informal to formal) of Krishan Nagar.
\end{abstract}

Keywords: British, colonial, Lahore, Urban reforms, modern planning, spatial structure, street scape, public realm, socio-cultural

\section{Introduction}

Lahore encompasses its history over thousand years. Latif described that in mid-seventh century Lahore was an important Town, however, actual date of its foundation is unknown (Latif, 1892, p.4). Lahore city was not planned deliberately but evolved slowly; maintaining traditions, cultures and historical structures for coming generations. The city, with characteristics of informality and concern for human senses, was established neither by one ruler nor in one period. The city also known as the Walled City due to fortification by a wall. The walled city represented a complex web of cultural and social activities with interwoven private 
and public spaces. The street space had integrated relationship with the flanking buildings. The convoluted streets of the city were often wide as much as required for pedestrians. Tall buildings in the winding and twisting streets used to provide cooling relief below by protecting the thin streets from severe sunrays. (Yasin, 2011).

The city, since its creation, lived under several rulers but experienced its glory under Mughal period (16th century A.D-18th century A.D.). In seventeenth century the Lahore was considered among the richest and prosperous territories of the Mughal period (Mahmood Mayo, 2012, p.87). Mughals not only took care of architectural and built environment of the city but added wonderful urban landscape with the creation of more than 50 gardens. (Mughal, 2005). Urban development during Mughal period was mostly focused on development of capital cities with their architecturally rich stronghold buildings, planned settlements and military cantonments. (Aziz, et al., 2014). City was divided into 9 Guzars for administrative purpose and was fortified for defence purpose during Mughal period.

The Sikhs ruled the city for nearly half a century from 1799 to 1849 . This period was characterized by a political turmoil hence there was substantially less activity with reference to urban expansion of the city. Even the suburban developments started to diminish as the city was confined to its wall. Hence in 1812 a second circuit to the fortification was added by Ranjit Singh, the Sikh emperor, which was separated from original fortification wall by a moat. Along with the addition of monumental built environment (gurduwaras, hawalies, temples) to the city, Sikhs added around 24 more gardens to the landscape of Lahore (Mughal, 2005). In addition they established a military cantonment in the area surrounding the Tomb of Anarkali on the Southwest of the city

The British entered Lahore after defeating Sikhs in 1846. Fortification wall around the city was demolished and cantonment was established by the British. Unlike walled city bazaars, Bazaar at Cantonment was developed with straight streets and sewage facility to serve troops and their families. For civilian officers Civil Line (GOR ${ }^{1}$ and Mayo Garden) was established (Shirazi, 2007). A change in urban network took place with straight roads having trees along them (Naz \& Ashraf, 2008). In contrast to walled city's convoluted and irregular streets, Civil Line was characterised with straight roads and 
segregated residential and commercial activities (Qadeer, 1983, p.82). This new concept of urban layout and amenities like sewage, water supply and electricity brought major change in city's urban settings and socio-cultural development. (Refer Figure 1 Here)

Municipal committee was formed in 1911 by British and New Indigenous Communities were developed by this committee with segregated spaces for various activities i.e. separate play grounds and educational institutions along with religious buildings were also provided. These new schemes were developed in open areas all over the city, following the pattern of Cantonment and Civil Line. The streets and plots were properly surveyed by municipal engineers in these schemes (Rehman, 2013, p.182) .Straight roads were wide enough for vehicles and the houses were constructed according to modern style. The residential streets were arranged in rectangular blocks and radiated from main the commercial street. In the late colonial era these were actually middle class localities (Talbot, 2006, p.13). In the houses of these areas, roofs of the rooms were high like British bungalows. Despite of these modern town planning principles, Culture and architecture of these new indigenous schemes were enhanced variant of the walled city as the residents are mostly the migrants from walled city (Talbot, 2006, p.171).

In order to meet the increasing housing requirement the cooperative societies act was passed in 1912 which lead to the formation of Lahore Improvement Trust (LIT). Housing accommodation, expansion schemes, rehousing schemes and all street schemes were prepared by LIT (Lahore Improvement Trust).

Krishan Nagar (a New Indigenous Community), developed under municipal laws and supervised by engineers, changed the face of Lahore: the layout of streets, architectural design of buildings and lifestyle of the people. What kind of changes in urban setting of these schemes happened under these modern urban planning principles by British? What are the effects or consequences of these modern urban settings? How these reforms influenced the traditional way of livings and street life of natives? To answer these questions following four aspects of Krishan Nagar are selected to open up the scenario of acceptance and negotiations by natives.

1. layout pattern (from organic to rectilinear)

2. streetscape (from Picturesque to negotiated) 
3. public realm (from sovereign to constrained)

4. socio-cultural dimensions (from informal to formal)

These aspects are explored by comparing the walled city's urban setting and spatial structure with the Krishan Nagar's. Delhi Gate Guzar of walled city is taken as an

\section{Layout Pattern (from organic to rectilinear)}

Krishan Nagar ${ }^{2}$ was planned according to modern planning principles under the influence of Civil Lines and Cantonment's urban settlement with amenities like green open spaces and play areas.As Qadeer (1983) mentioned that walled city was considered crowded, unsanitary and unsafe for imperial army (p.82). According to colonizer the walled city, was unsafe, unhealthy, inefficient and ungovernable. Rationally ordered city with; low densities, orthogonal forms, tree lined boulevards and distinct land use were ideals in colonizer's vision These essentials were exclusively realized in the Civil Lines and Cantonment (Hosagrahar, 2005, p.47). Krishan Nagar and other indigenous communities were designed according to the new vision but with compromises. For example the land use was not completely segregated deliberately in New Indigenous Communities as it was evident in example of traditional planning. Both areas of study are discussed under above mentioned headings as follows:

(Refer Figure 2 and Figure 3 Here)

Cantonment and Civil Lines. Roads were rectilinear and wider than the walled city but not the tree lined boulevards. These compromises were deliberately maintained to establish the distinction between colonizers and colonized to demonstrate the authority through the strategy of unfair treatment out of prejudice. As Bhabha remarked that colonial subjects were differentiated and rejected when they were expected to become 'like' ((Hern'andez, 2010, p.44).

The Public Health Act of 1857 brought the idea of wide and straight streets and Bye-Laws were determined to realize this approach of wide and straight streets with sewage and drainage systems (Broadbent, 1990, p.114). Depth of foot path and projections from the buildings into the street were determined under strict Bye-Laws, unlike walled city where these were the user's prerogative. These Bye- laws were meant for tangible realization of colonizer's vision of ideal and civilized city. Andrew 
Lee's idea of civilized city is in agreement with colonizer's idea as he says "An ordered city manifests society's civilization" (as sited in Hosagrahar, 2005, p.53). As a result, contrary to walled city's organic layout Krishan Nagar was geometrically (rectangular and semicircular) laid out with major roads intersecting each other at right angle. There was hierarchy of street layout in Krishan Nagar. The streets were laid out in primary to secondary and then tertiary arrangement. Widths vary in descending order from major or primary streets to minor (tertiary streets). Streets were at short intervals as each residential block had maximum six houses. Two parallel streets were subdivided with back to back plots spacing. Secondary and tertiary streets were perpendicular to each other and also at right angle to Major Street making inner streets open to primary (major) street without any visual hindrance. Carmona et al. observed from previous studies that in ideal situation street should be an enclosed unit! Dwellers feel comfortable in a space when their impressions are confined within that space and gaze is not lost in infinity' (Carmona, et al., 2012, p.141). In contrast here in Krishan Nagar's layout user can see other street's end easily without the feeling of confinement. As minimum street width is 12-18feet (Qadeer, 1983, p.181) with major streets 40 feet wide making less feeling of enclosure. Main streets were mainly commercial with shops on both sides of street (Qadeer, 1983, p.83).

(Refer Figure 4a Here)

Quite the opposite of Krishan Nagar's spatial structure walled city had meandering streets. Primary or major streets were winding from one end to another. These streets were never in a straight line, thus induce visual hindrance. Each passer by receives element of surprise at every corner in the form of architectural form or location of buildings (Rehman, 2013, p.174) along with the feeling of confinement as minimum street width reaches till 2'-6". Narrow dead end alleys radiated from these primary/major streets provide access to different parts of the neighbourhood. These narrow dead end streets (cul de sacs) were extremely private and personal. As Kunstler (1996) mentioned that "The cul-de-sac streets are safer from evil doers" (p.129). Such winding and twisting street system was preferred in medieval times as it gives control in resident's hand to make the area safe from invaders and outsiders.

\section{(Refer Figure $4 b$ Here)}

While simple and straight grid pattern invites criminals, speeders, and homeless to find their way into neighbourhood 
(Ford, 1999). Since colonizer wanted to take control from natives and control neighbourhood by themselves, therefore, rectilinear pattern was proposed by British officers. For colonizer unpredictable character of mysterious winding lanes made them inaccessible and threatening. Daara (2008) remarked that the idea of winding and twisting street transformation into more straight was not only based on health issues but the systematic plan of communication was the underlying fact (p.10). According to Western World's ideals of; Civilization, sciences and discipline, the maze of narrow twisting streets is irrational, traditional and superstitious. Moreover, it indicates the social decline (Hosagrahar, 2005, p.65). Therefore, modern town planners did not seek inspiration from urban history in terms of spatial layout and urban form. Resultantly, street lost its actual characteristics of intermediate position between; private and public, individual and social life and the human dimension of street space (Daara, 2008, p.V1). For instance, Le Corbusier acknowledged that walking experience in twisting street may perhaps be a better one than in a straight street, but did not extend this assessment (Corbusier, 1929, P.208). Sitte (1889) wrote about such a modern planning technique: "one can observe a wide spread satisfaction with that which has been so well accomplished along technical lines--in respect to traffic, the advantageous use of building sites and, especially, hygienic improvements. In contrast there is almost as prevalent a condemnation of the artistic short comings of the modern city planning, even scorn and contempt. That is quite justified; it is a fact that much has been accomplished in technical matters, whilst artistically we have achieved almost nothing" (as sited in Broadbent, 1990, p.117).

\section{Streetscape (from Picturesque to negotiated)}

Streetscape is an apparent view and environment of street (Merriam-Webster., n.d.). Street ambiance with vivid pictorial qualities and striking impressions is the picturesque one (Dictionary.com, n.d.). Picturesque streetscapes have always been in discussion of urban designer and planners, particularly, the designers with traditional views of urban design and planning. Julian Gaudet strongly emphasizes on the picturesque characteristics of streetscape and says, "I adore the picturesque and certainly, (when) a stranger ...arrives in a town (it is) the picturesque that seizes him most" 
(as sited in Broadbent, 1990, p.120). Lahore was introduced to modern urban planning principles those were considered more practical and functional by colonizer. As in later studies it is claimed that urban planning policies got shifted from traditional planning policies to modern planning principles and theories that are based on utilitarian and functional requirements (Taylor, 1999) Twisting and winding streets of walled city with; the consistency of Inconstancy in the widths and lengths of shades, projections and also the building heights, were criticised by British. Hence, Krishan Nagar and all other indigenous communities were planned according to Bye-Laws with The wide, straight and continuous "Bye-Law" street. However, Geddes (1949) was very much inspired by the beauty of walled city and described it as a gorgeous city. He was not in favour of mechanically laid straight street pattern and mentioned it as monotonous and rigid. He described precolonial picturesque street layout as an outcome of practical life of centuries. (Rehman, 2013, p.124) Similarly, Sitte considered rectilinear system as a step towards loss of street character and emphasized winding lanes by saying that "confusion is beautiful" (as sited in Broadbent, 1990, p.135). Correspondingly, Cullen's theory of serial vision also becomes irrelevant in grid iron patterned "Bye-Law" streets. (Cullen, 1961)

A space, with variety and human-scale detail and the quality of richness i.e. variety of things to look at (Bentley, 1985, p.146) acts as a source of attraction and encourages walkability. Such physical features, present in the walled city streets, make it a place to walk rather than the urban motorway. Given that, no Bye-Laws restricted the heights and widths of the buildings addressing to street as well as; entrance steps, balconies, windows, wood work details and other eye engaging architectural features (Watson, et al., 2003, P.64). Jharokas of varying sizes also enhance the richness of the space as well as the thresholds and arch ways adds to the striking expression of the walled city streets. Balconies were source of visual richness. In addition these were the favorite place of the elder of family who enjoy staring passerby below while sitting in balcony along with the pleasure of hookah ${ }^{3}$ (Hosagrahar, 2005, p.62). All of these things have augmented the scenic beauty and delightfulness of the street. People feel free and enjoy the spaces with such a character.

(Refer Figure 5 Here)

A person walking through the walled city streets spontaneously experience the 
colourful textures and busy facades of the streets. Such experience of spaces in walled city streets with informal organization of different spaces makes them pleasing. Gaudet opposed the imposition of Bye-Laws for picturesque and sees the absence of regulations in the past as a key factor in the growth of the picturesque (as sited in Broadbent, 1990, p.121). In Krishan Nagar Municipality imposed laws for; property lines, projections, height of the adjoining buildings as well as standard for maximum protrusion for first floor and cantilevers. Therefore the picturesque streetscape was compromised not only with the straightness and wideness of streets but with above mentioned Laws. Though residents were not fully convinced with the restrictions therefore, semi-formal character of street is found in Krishan Nagar. This streetscape in Krishan Nagar is neither in compliance with the modern planning principles (colonizer) nor with the traditional walled city.

\section{(Refer Figure 6 Here)}

Streets in Krishan Nagar have definite start and end with no zigzags and accidental conjunctions. The accidental conjunctions are a common feature of walled city streets. Sitte liked these conjunctions in medieval cities and visualizes picturesque and sensory delight with zigzag streets, recurrent interruptions of building line, uneven street width, different heights of houses balconies, loggias etc. (Larice, 2013, p.51) Laws enforced by colonizer were in opposition of Sitte's mental picture of picturesque.

(Refer Figure 7 and 8 Here)

Although in Krishan Nagar people did not follow thoroughly the strictness of property line and also the maximum projection limits. But few things like; bulge in street, strong curves and sudden narrowing of streets, (present in walled city streets), were deliberately kept away from the layout of New Indigenous Communities. The bulged spaces gave the passer by a different and pleasant experience. The change of experience was accentuated when coming from a narrow street; the user got introduced to this very space.

(Refer Figure 9 Here)

Streetscape in the walled city varies almost after few hundred yards due to diverse activities and their various combinations (Qadeer, 1983, p.177). In pre-colonial bazaars, Shop keepers displayed their items on to main streets, and extended their work place temporarily through pedestrian space. A Hawker and a vendor were also not constrained. Usually the work benches of shop keepers lie in street space. At Krishan Nagar the way 
shopkeepers displayed their items resembles as in walled city streets, though again restrictions were imposed on shop keepers for extended displays. Hawking and vending was made possible only by paying money to the municipality. Resultantly, due to the constraints though not completely followed, the spontaneity of colonial bazaar is negotiated in comparison to pre-colonial one. Jyoti mentioned the same situation in Delhi when efforts of municipality to draw formal boundaries of public and private space in streets did not succeed (Hosagrahar, 2005, pp.74-75). Taking Delhi Gate (Walled City Lahore) area as an example of streetscape in pre-colonial settlement the main thoroughfare leads towards the masjid Wazir Khan with no clue of having such an amazing building of mosque at an end with the decoration of brick imitation work and enamel tiles. Passerby enjoys the accidental conjunctions and informal property line of bazaar with work benches of shopkeepers extending on to the street. Shops on ground floor with vibrant display and first floor for residence purpose with interplay of bukharchas ${ }^{4}$ and Jharokas ${ }^{5}$. Then the street took a slight turn at Chitta Gate before passerby arrives the grand square of Masjid (Rehman, 2013, p.174). Thus a delightful experience of prosperous bazaar with rich details ends at surprisingly amazed building (Masjid Wazir Khan). Such a picturesque experience is missing in Bye-Law Street developed by colonizer. (Refer Figure 10 Here)

\section{Public Realm (from sovereign to constrain)}

Pleasant and comfortable environment are the qualities of public space/street that makes it a conduit with dominant pedestrian realm. The substance and convenience of a street in the NICs was illustrated in 1911 ACT as: the streets are the main source to get well ventilated buildings thus, increase in width of street not only adds convenience of layout but also for the people living on those streets (Rehman, 2013, pp.202-207). Streets at Krishan Nagar are wide as compare to walled city street. Here the minimum street width is 12 feet as compare to walled city street where it is 2'-6"'. These streets provide better through air and light adding to comfort ability of user's experience but were not as adequate as were aspired in 1911 ACT. This was described by Aylmer Oates in his annual report 1938-39 that these schemes suffered from poorly positioned roads of insufficient dimension, plot sizes are inadequate not only for healthy buildings but also for through air 
due to little open space provisions around the buildings. He also mentioned lack of open spaces for public services and recreational purposes: Geddes was also concerned for ventilation through open and wide streets. He proposed a street width of 40 feet sufficient for proper ventilation and a 20-foot wide street was considered too narrow. As 3 to 4 feet balcony projection on both sides make a 20 feet wide street too narrow for proper ventilation. (Rehman, 2013, p.124).

In a public space people feel satisfied when spaces are comfortable and provide opportunities of discovery and active and passive engagement (Carr, et al., 1992, p.19). Walled city's twisting streets with no definite building line and with ever changing experience of convex and concave spaces provided perfect play of discovery and exploration.

(Refer Figure 11 Here)

Since streets in Krishan Nagar were straight and at right angle to each other. A person standing at one corner of street could easily watch the other corner of street thus eliminating the element of surprise and discovery present in walled city streets where passer-by hardly had clue about the happenings at the end of street. Junctions of secondary streets with the primary streets were regular and aligned making the layout more formal and reducing the interest of user due to this same repeated aligned formality. Sitte also pointed out this drawback and considered rectangular system a reason of loss of street's character (Sitte, et al., 1945, p.45).

$$
\text { Enriched visual }
$$

experience adds to the pedestrian realm by adding active and passive eye engagement on street. In both residential and commercial streets buildings have overhangs on street façade. Though there was limitation and standard set in 1911 ACT for overhangs and balconies, nevertheless, mostly residents belonged to Walled city and could not totally abandon the culture of; so much exaggerated projections that rooftops were often used to visit each other, the way of their livings and constructing. Therefore, people in Krishan Nagar tend to extend beyond the limits. Bhabra (2012) describe this very quality of native people to retain their culture as; "India was in sum a living museum' where ancient customs, habits, and practices endured (persisted) up to the present".( p.112) William Glover (2007) mentioned this very character of native as "there is a certain pleasure involved in subverting authority". These overhangs have different length, height, width and forms that add to richness of visual experience. These overhangs have different; length, height, width and forms 
that add to richness of visual experience. In addition, these served as shade in hot summers and relief space for pedestrians with the provision of weather protection (Bentley, 1985, p.10) .Bhabha coined the word hybridity for this very struggle of adherence of people with their conventional things though transformed (Hern'andez, 2010,p.77).

\section{(Refer Figure 12 and 13 Here)}

Streets with the quality of pedestrian realm persuade people to walk that enhance the chances to have surprise encounter with a friend. Such encounters add to liveability of streets making it less deserted and less prone to crimes as Jacob described, unsafe street are those with less pedestrians (Jacobs J. , 1961, p.30) Whyte carry argument further that presence of people in urban space is required to join other people, as people attract people (Whyte, 1980, p.19) Streets at Krishan Nagar are less safe than walled city streets since, these streets offer less interest to pedestrians as mentioned above.

\section{Socio-Cultural Dimensions (from informal to formal)}

New Indigenous Communities planned by engineers under British Raj brought new social order (Qadeer, 1983, p.82). Socio
Cultural Values became more formal and different from Walled city's informality. Since people in the walled city streets tend to linger as the space had rich visual experience, which in turn caused frequent eye encounters thus adding socializing and chances of mingling. This is the characteristic of a space with aesthetic experience (Isaacs, 2000) . In addition, Spaces with low limits and bounds have the quality of robustness. People in such spaces usually feel free and enjoy them according to their own will. Every person could built his house according to his own desires without the fear of laws. As a result the street scenes appear robust making it healthy and vibrant space. Hassan Fatehy stated the same rule under the heading "Saving the individuality" while designing the Gourna village (Fathy, 2000, p.46). All these things build a strong bond; between people with other people and people with things in the territory of urban space (Rapaport, 1982, p.179), making Walled city's urban space with the people having strong connections between places and their personal lives (Mla, May 2006, p.42; Carmona, et al., 2008, p.12).

\section{All new Indigenous}

Schemes were developed under the Municipal Act. These schemes had restrictions for the use of public space since, property line between street space 
and personal space was marked. People living in these schemes had fear of law enforcements. Residents were unhappy against the loss of their right to privatize their street space. It was found people were having one or two entry steps beyond their property line. Same condition was true for depth of projections. Geddes (1949) was also opponent of aggressive approach to apply modern urban settings rather he was in favour of conservation surgery. He said "Cities required changes and improvements with the passage of time but any change must retain the "character and spirit of the city" (as sited in Rehman, 2013, p.123) .On contrary, the interventions by municipality were in disrespect of already existing social and cultural norms of residents. For instance, Windows and balconies opening in the street made them not only gregarious but provided residents with the capacity to observe without being seen (Dosen \& Ostwald, 2013). This capacity of observation gives the psychological feel of security to observer and adds enjoyment of seeing others without being seen. In Krishan Nagar, windows and balconies also address the street scene. Nevertheless, the use of balconies and windows is not informal and enjoyable as it would in walled city streets. Hardly women were spotted in balcony space, because, streets in Krishan Nagar did not provide visual privacy and kept outsiders away. This was true in walled city streets which were never straight (Rehman, 2013, p.174) and offered mystery for new comers.

\section{(Refer Figure 14 and 15 Here)}

Generally land use pattern of Krishan Nagar was more like the walled city rather than Cantt. and Civil Lines. Shops are so nearby to residences that grocery can be done conveniently for every meal reducing the refrigerator dependency (Qadeer, 1983, p.181). But there are few major changes that affected the sociability of space. For instance, streets in walled city were used as house extensions. Women in streets often stand in the doorways or sit on the steps of the doorways. They used to chat informally with each other because physical design of a street provides shade from scorching summer sunlight viz. a viz. Privacy. Standing at doorsteps and talking with neighbour is very common in our indigenous settings. As women within the boundary of their home feel secure and also feel free to socialize. Furthermore, Children feel untroubled sitting on the house entry steps as these were part of their own home. Marans \& Stokols (1993) remarked the same way that urban space is the expansion of our private domain (Alkhresheh, 2007, p.33).

(Refer Figure 16 Here) 
Due to rules and regulation in Krishan Nagar this expansion of private domain into public was restricted under the strict umbrella of public and private property bounds as compare to walled city where it was determined by inhabitants. Mostly nobles of Mohallas used to solve the disputes regarding use of property space as well as the other matters of residents.

Mohallas (neighborhoods) not only served as loci of family (Qadeer, 1983, p.176) but also they would become more rich and diverse with passage of time (Ford, 1999). In addition, Walled city's physical layout have spaces that adds the factor of Sociability. Katrah ${ }^{6}$ is the best example of such spaces. For residents it serves as an outdoor room, as it provides great privacy. This quality of privacy is due to its position in the street with blind end. This particular place provides room for kid's play and women's chitchat. Katrah acts like a home territory for people who are residing around. Because houses are small, and several happenings like; old people sitting on charpai in the evening with youngsters sitting around, parking of vehicles and play of children with their neighbouring friends cannot be accommodated within the house. There is minimum fear of unknown and sense of strangeness because stranger hardly visit Katrah due to dead end of street (Yasin,
2011). Katrah was a space where rich and poor lived side by side. Playing, sleeping and other activities were happening in this particular space as inside the house (Qadeer, 1983, p.177). Rectilinear layout of Krishan Nagar does not provide any room for such spaces. Therefore this particular social space became obsolete in all communities developed under modern planning principles making them dull and less sociable.

\section{(Refer Figure 16 Here)}

Since the design is powerful tool to change the society (Thorpe \& Gamman, 2011) Hence, colonizer used architecture design as powerful mean to bring new social order (Hern'andez, 2010, p.16). Resultantly, New Indigenous Schemes have not such a strong connections between people and places due to lack of abundance of outdoor informal spaces with minimum privacy from strangers.

\section{Conclusion}

Urban reforms in colonial India brought changes in the way the city was envisaged, if not always in the manner it appeared (Glover, 2007). Different design aspects of urban space were changed by colonizer that influenced the public realm, visual experience of streetscape, layout pattern and socio-cultural values of colonized. 
Imposition of Bye-Laws affected the possible realm for movement, informal interaction and activities of lingering and strolling and the neglect and reduction of the street space from the transitional space to a public space.

Modern planning principles by Colonizer brought the concept of public space and private space with strict boundary line in between. As a result, Informal sitting places like tharras and stoops in front of shops laying on street space were considered under municipality. The use of those spaces were no more the shop keeper's right, rather the user or shopkeeper became accountable for it quite opposite to the walled city street's scenario . In case of walled city streets tharras and steps both in commercial and residential areas were considered as extension of property. Shop keepers and residents enjoyed the rights to use them as per their readiness. People sitting on stoops or secondary seating places kept on sitting for a while or at times for long time as because they were involved in interesting activity of watching others. Such space both in commercial and residential areas brought liveliness as people would keep sitting there since "people tend to sit when they get place for it". (Whyte., 1980, p.28) Christopher and Jan Gehl mentioned such spaces as secondary seating spaces (Alexander, et al., 1977, pp437-439; Gehl, 2013, p.142; Carmona, et al., 2008, p.14), that were officially not designed for public realm but over the centuries through their use had acquired particular character and became important for user with repeated shared experiences (Carr, et al., 1992, p.20). In Krishan Nagar's bazaars such stoops were built in a space that is, according to law, a space for pedestrian or foot path and not included in property of shopkeeper. People could not restrict themselves in boundaries of public and private property and those spaces were used by shop keepers as it was accustomed in walled city. In Krishan Nagar this space was 8feet on main thoroughfares or Bazaars. For instance, main Islampura Bazaar Street is 30feet wide plus 8 feet space for foot path. In pure Residential areas or in tertiary streets these steps were part of property and according to Bye- Laws could not be extended out of the property line. Violation and acceptance of rule was found simultaneously as one or two steps were built in public space rather than all as it was found in walled city residential streets (12).

In Krishan Nagar streets were not only wide enough but also straight. Passer-by can see the other end of street without any difficulty due to 
orthogonal layout. Bye-Laws for; overhead projections, width of pedestrian sidewalks and height of the buildings flanking the street reduced the spontaneity. According to the report of $1938-39$ prepared by British Officer, the increase in Street width and decrease in length did not serve the desired purpose of healthy environment with through air but this change caused loss of beautiful characteristics of traditional street space i.e. enclosure and feeling of confinement

As people were mostly migrant from walled city they were unable to follow the rules strictly. For few Laws (tharras and entrance steps) they showed defiance and for others (lack of highly private spaces like convoluted tertiary street and Katrah) they just compromised as a result reforms were negotiated. Therefore Krishan Nagar appeared as a mixture of elements of both colonized and colonizer where People accepted modern setting on the cost of human dimension like walkability, sociability, informality and with the loss of intermediate position of street space between private and public activities. Traditional use of balconies and Jharokas made the street space more safe, lively and sociable. That was not followed with the same zeal in Krishan Nagar because streets in walled city provided visual privacy. As passer-by moves from primary to secondary and then tertiary streets public space would become more secure and private respectively. Outsiders were hesitant to visit meandering layout making it more secure for women to sit on doorsteps, children to play in street space and elder women to enjoy balcony space. Loss of Katrah space in modern settings created a huge disruption in sociable quality of street space. Traditional street settings are rich with such elements. All these things are perhaps not imperative pragmatically but have romantic associations. Michael Graves (2005) gives the example of candle to highlight the importance of conventional things:

"We enjoy the flame's warmth and its special kind of light. It isn't pragmatically necessary, but socially it's an agreeable thing to do; it's romantic. It's a convention that we have a hard time giving up even though we have other more sophisticated means of warming and illuminating a room. I suppose the reason we haven't given up on the candle is because we'd be missing out on the magic of the experience." (p.251)

Thus it is cogent to study in detail the effects of urban reforms by colonizer to open up the scenario of reduction of romantic and traditional characteristics of urban space. Modern planning principles influenced the way of 
ISSN 2394-9392 (Online); DOI: 10.16962/EAPJSS/issn.2394-9392/2014; Volume 2 Issue 2 (2016)

livings of natives particularly the street

life. It is needed to explore further aspects

of spatial structures of New Indigenous

Communities to establish the adaptable

planning principles for natives

\section{REFERENCES}

[1] Alexander, C., Ishikawa, S., \& Silverstein, M. (1977). A pattern language: towns, buildings, construction (Vol. 2). New York:

Oxford University Press.

[2] Alkhresheh, M. M. (2007). Enclosure as a function of heightto-width ratio and scale: Its influence on user's sense of comfort and safety in urban street space. University of Florida. Florida: University of Florida. Retrieved may 17, 2015, from http://www.dissertation.libebook.com/d-philosophy/25980331-by-majdi-alkhreshehdissertation-presented-thegraduate-school.php

[3] Ambroziak, B., \& Graves, M. (2005). Michael Graves: Images of a Tour. New York: Princeton Architectural Press.

[4] Aziz, A., Mayo, S. \& Ahmad, I., 2014. Master Planning Under
Legislative and Organizational Impediments (A Case Study of Lahore)\},. Technical Journal, University of Engineering and Technology (UET) Taxila, Pakistan, Volume 19, pp. 34-42.

[5] Bentley, I. (1985). Responsive environments: A manual for designers. (I. Bentley, Ed.) London: Routledge.

[6] Broadbent, G. (1990). Emerging concepts in urban space design (1st ed. ed.). New York: E \& FN Spon.

[7] Carmona, M., de Magalhães, C., \& Hammond, L. (2008). Public space: the management dimension. London: Routledge.

[8] Carmona, M., Heath, T., Oc, T., \& Tiesdell, S. (2012). Public places, urban spaces: the dimensions of urban design. London: Routledge.

[9] Carr, S., Mark, F., Rivlin, L., \& Stone, A. (1992). Public Space: Environment and Behavior Series. (D. S. Altman, Ed.) New York: Cambridge University Press.

[10] Corbusier, L. (1987). The city of to-morrow and its planning, by le corbusier. US: Courier Corporation. 
[11]

$$
\text { Cullen, G. (1961). The }
$$

concise townscape. London:

Routledge. of the dynamics of the street space: The case of streets in three major areas in Constantine. Ph.D. dissertation, BUC University Constantine 1 (eg Mentouri) - BP 325 Constantine Ain El Bey Road, 25017 Constantine, Algeria. Dictionary.com. (n.d.).

Retrieved june 15, 2015, from http://dictionary.reference.com/: http://dictionary.reference.com/bro wse/picturesque

[14] Dosen, A. S., \& Ostwald, M. J. (2013). Prospect and Refuge Theory: Constructing a Critical Definition for Architecture and Design. The International Journal of Design in Society, 6(1), 9-24.

[15] Fathy, H. (2000).

Architecture for the poor: an experiment in rural Egypt. London: University of Chicago press.

[16] Ford, L. R. (1999). Lynch revisited: New urbanism and theories of good city form. Cities, 16(4), 247-257.
Geddes, P., Association, O. T., \& others. (1949). Cities in evolution. London: Williams $\backslash \&$ Norgate.

[18] Gehl, J. (2013). Cities for People. Washington: Island Press. design. London: architectural Press

Construing Urban Space as 'Public'in Colonial India: Some Notes from the Punjab. JPS, 14(2), 212.

$$
\text { Glover, W. J. (2008). }
$$

Making Lahore Modern: Constructing and Imagining a Colonial City. London: University of Minnesota Press.

[22] Hern'andez, F. (2010).

Bhabha for architects.

Oxfordshire: Routledge.

[23] Hosagrahar, J. (2005).

Indigenous modernities: negotiating architecture and urbanism. Oxfordshire: Routledge.

[24] Isaacs, R. (2000). The urban picturesque: an aesthetic experience of urban pedestrian 
places. Journal of Urban Design, 5(2), 145-180.

$$
\text { Jacobs, A. B. (1995). Great }
$$

Streets. Massachusset: Mit Press.

[26] Jacobs, J. (1961). The death and life of great American cities. New York: Vintage.

[27] Kunstler, J. H. (1996).

Home from nowhere. Atlantic Monthly, 278(3).

[28] Larice, M., \& Macdonald, E. (2013). The urban design reader (2nd ed.). Oxfordshire: Routledge. Retrieved august 7, 2015, from https://books.google.nl/books?id= NLOKzaB_rZQC\&printsec $=$ frontc over\&dq $=$ the + urban + design + reade $\mathrm{r} \& \mathrm{hl}=\mathrm{en} \& \mathrm{sa}=\mathrm{X} \&$ redir_esc $=\mathrm{y} \# \mathrm{v}=\mathrm{o}$ nepage \&q=the \%20urban\%20desig $\mathrm{n} \% 20$ reader $\& \mathrm{f}=$ false

[29] Latif, S. M. (1892). Lahore: Its History, Architectural Remains and Antiquities: With an Account of Its Modern Institutions, Inhabitants, Their Trade, Customs, $\backslash \& c$. Lahore: the New Imperial Press.

$$
\text { Lees, A. (1985). Cities }
$$

perceived: urban society in European and American thought,
1820-1940. Manchester:

Manchester University Press.

$$
\text { Mahmood Mayo, S., } 2012 .
$$

Determination Of Urban

Settlement Pattern For Optimal Regional Development In Punjab, Lahore: UET. Merriam-Webster. (n.d.). (An Encyclopaedia Britannica Company) Retrieved June 15, 2015, from http://www.merriamwebster.com/: http://www.merriamwebster.com/dictionary/streetscape Metcalf, B. D., \& Metcalf, T. R. (2012). A Concise History of Modern India (3rd Ed. ed.). New York: Cambridge University Press. Mla, P. R. (May 2006). PROSPECT-REFUGE THEORY REVISITED: A SEARCH. The University of Texas at Arlington. Arlington: ProQuest Information and Learning Company. Retrieved may 5, 2015, from http://kwul.kwu.ac.kr/oversea/5_14 35938.PDF

$$
\text { Moughtin, C. (2003). }
$$

Urban design: street and square (3rd ed.). Oxford: Architectural press. 
Mughal, M. R., 2005.

Impact of urbanization on ancient

gardenscape of Lahore and the

World Monument of Shalamar

Garden (Pakistan).

[37]

Naz, N., \& Ashraf, Z.

(2008). Transformation of Urban

Open Spaces of Lahore: From

Charing Cross to Faisal Square.

Pak. J. Engg. I\& Appl. Sci. Vol.

[38] Qadeer, M. A. (1983).

Lahore: Urban Development in the

Third World-. Lahore: Vanguard

Books.

[39]

$$
\text { Rapaport, A. (1982). The }
$$

meaning of the built environment.

Beverly Hills: Sage. CEO

Discourse in Mergers and

Acquisitions, 151.

[40] Rehman, A. (2013).

Mapping Lahore: Tracing

Historical Geography of a City

Through Maps. Lahore: Al-Mezaan

Publishers and Book Sellers.

[41] Shahzad, S. (2015, july 5).

Life Of Lahore Through Edwin

Lord Weeks Eye. Retrieved august

20, 2015, from http://lahore.city-

history.com/: http://lahore.city-

history.com/blogs/life-of-lahore-

through-edwin-lord-weeks-eye/
[42] Shirazi. (2007, March 2).

Chowrangi. Retrieved June 7,

2015, from www.chowrangi.pk:

http://www.chowrangi.pk/shifting-

lahore.html

[43] Sitte, C. (1986). City

planning according to artistic

principles. New York: Rizzoli.

[44] Sitte, C., Stewart, C. T.,

Sitte, C., Sitte, C. a., \& Sitte, C. a. (1945). The Art of Building Cities:

City Building According to Its Artistic Fundamentals. New York:

Reinhold Publishing Corporation.

[45] Talbot, I. (2006). Divided

Cities: Partition and its Aftermath

in Lahore and Amritsar 1947-1957.

Oxford: Oxford University Press.

[46] Taylor, N. (1999). Anglo-

American town planning theory

since 1945: three significant developments but no paradigm

shifts. Planning Perspectives,

14(4), 327-345.

[47] Thorpe, A., \& Gamman, L. (2011). Design with society: why socially responsive design is good enough. CoDesign, 7(3-4), 217230.

[48] Watson, D., Plattus, A. J., \& Shibley, R. G. (2003). Time- 
ELK ASIA PACIFIC JOURNAL OF SOCIAL SCIENCES

ISSN 2394-9392 (Online); DOI: 10.16962/EAPJSS/issn.2394-9392/2014; Volume 2 Issue 2 (2016)

saver standards for urban design.

New York: McGraw-Hill.

[49] Whyte, W. H. (1980). The

Social Life of Small Urban Spaces.

New York: Project for Public

Spaces.
[50] Yasin, A. (2011). The Lost Romance Of Streets Of Lahore. Portrait of Lahore (pp. 173-186). Lahore: Thaap Publication.

\section{ILLUSTRATIONS}




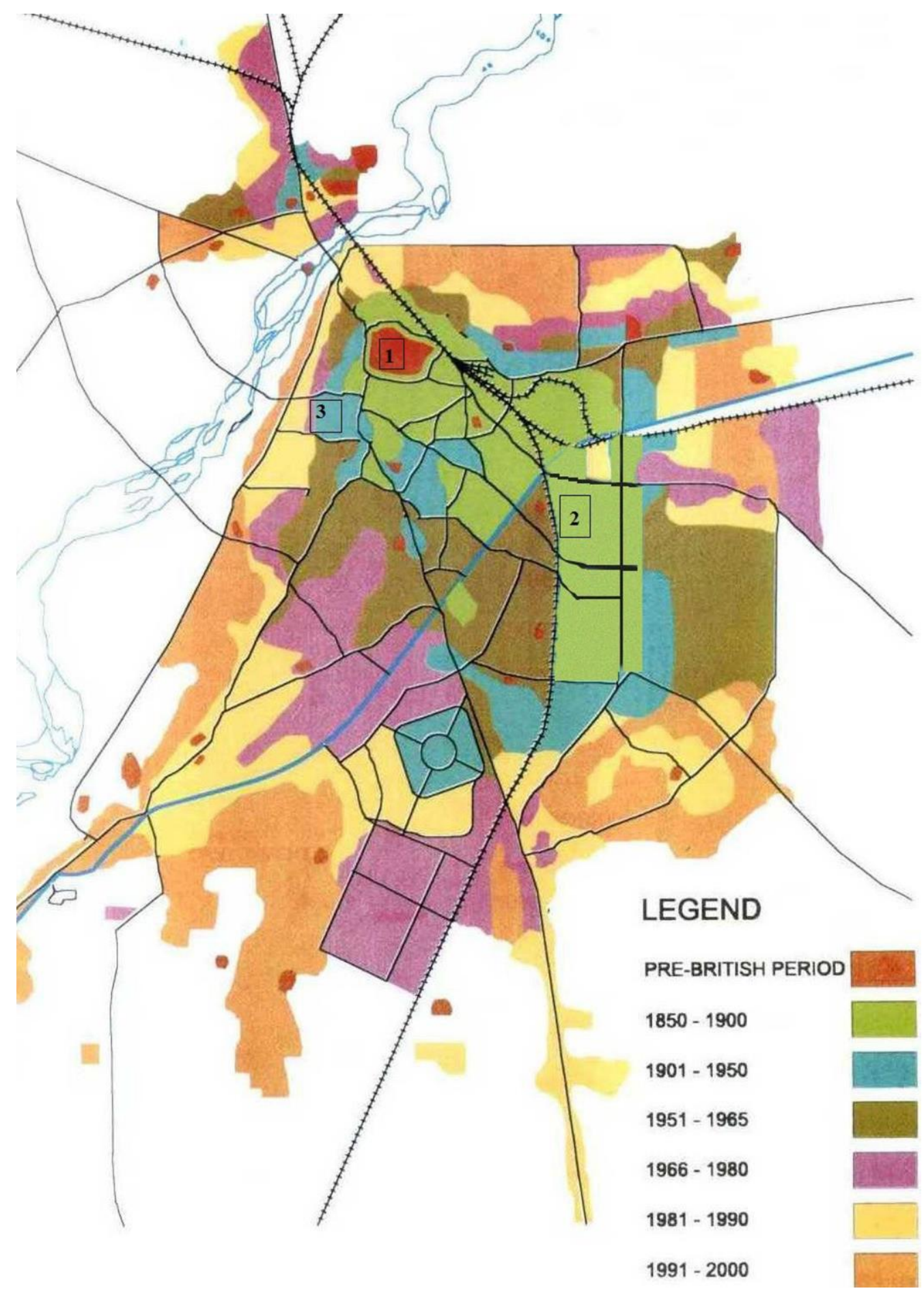

Figure 1. Historical Growth of Lahore Source: Nespak 2009. 


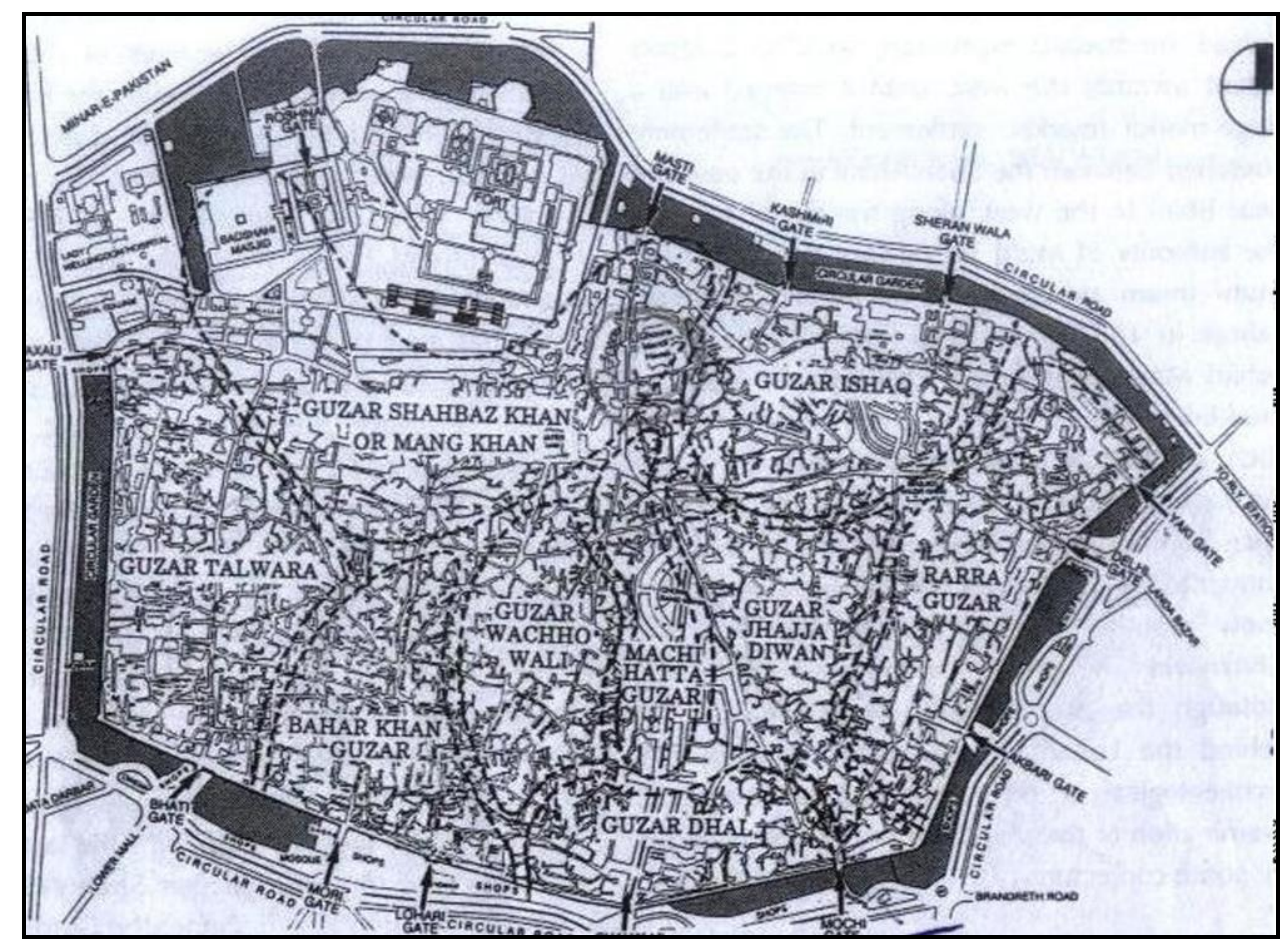

Blow up detail: (1) .Walled city (pre-colonial period): Organic growth of city with twisting streets. Source: Pepac ${ }^{7}$

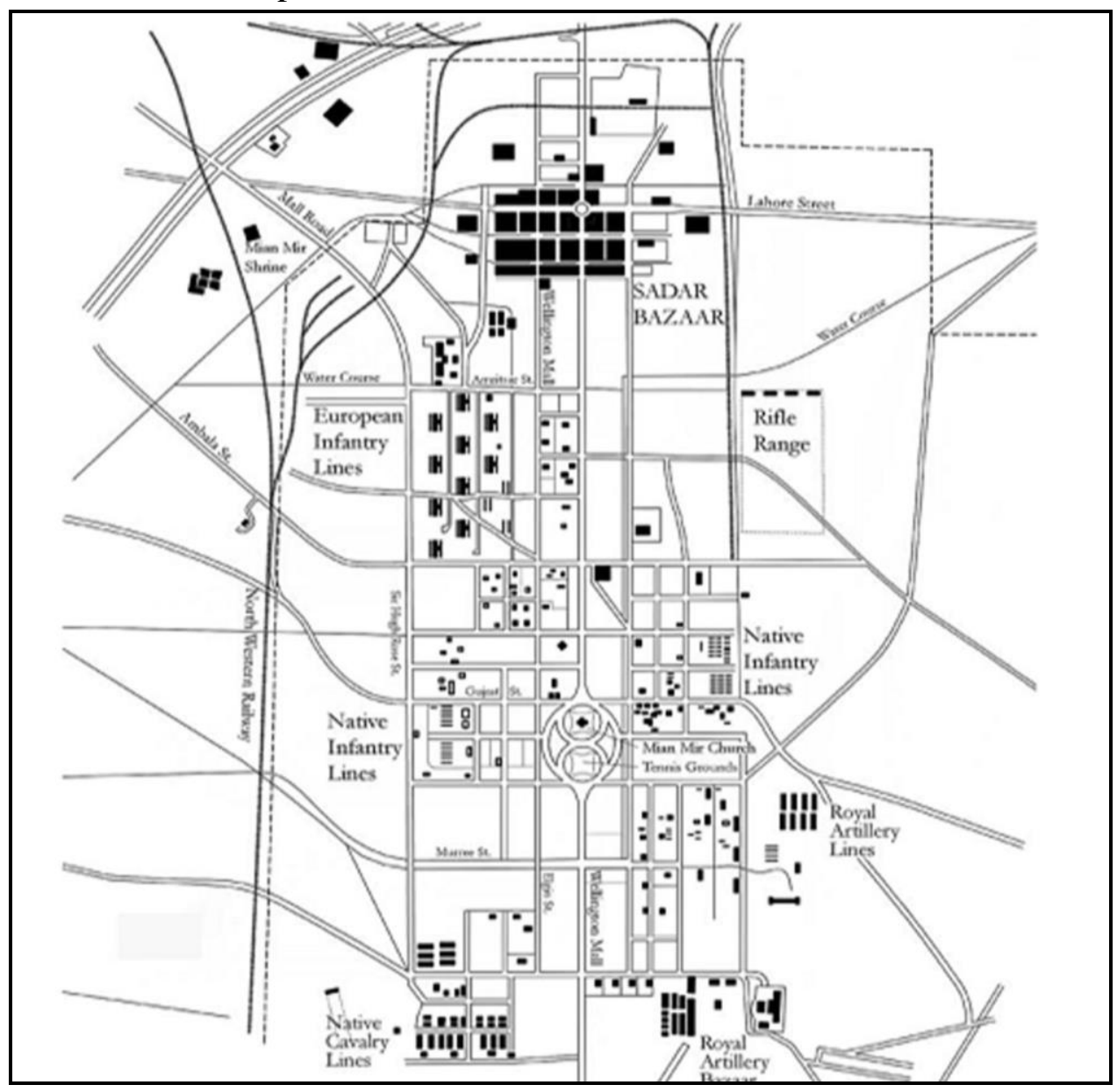


Blow up detail: (2) Cantonment (early colonial era): Planned according to new vision.

Source: (Glover, 2008)

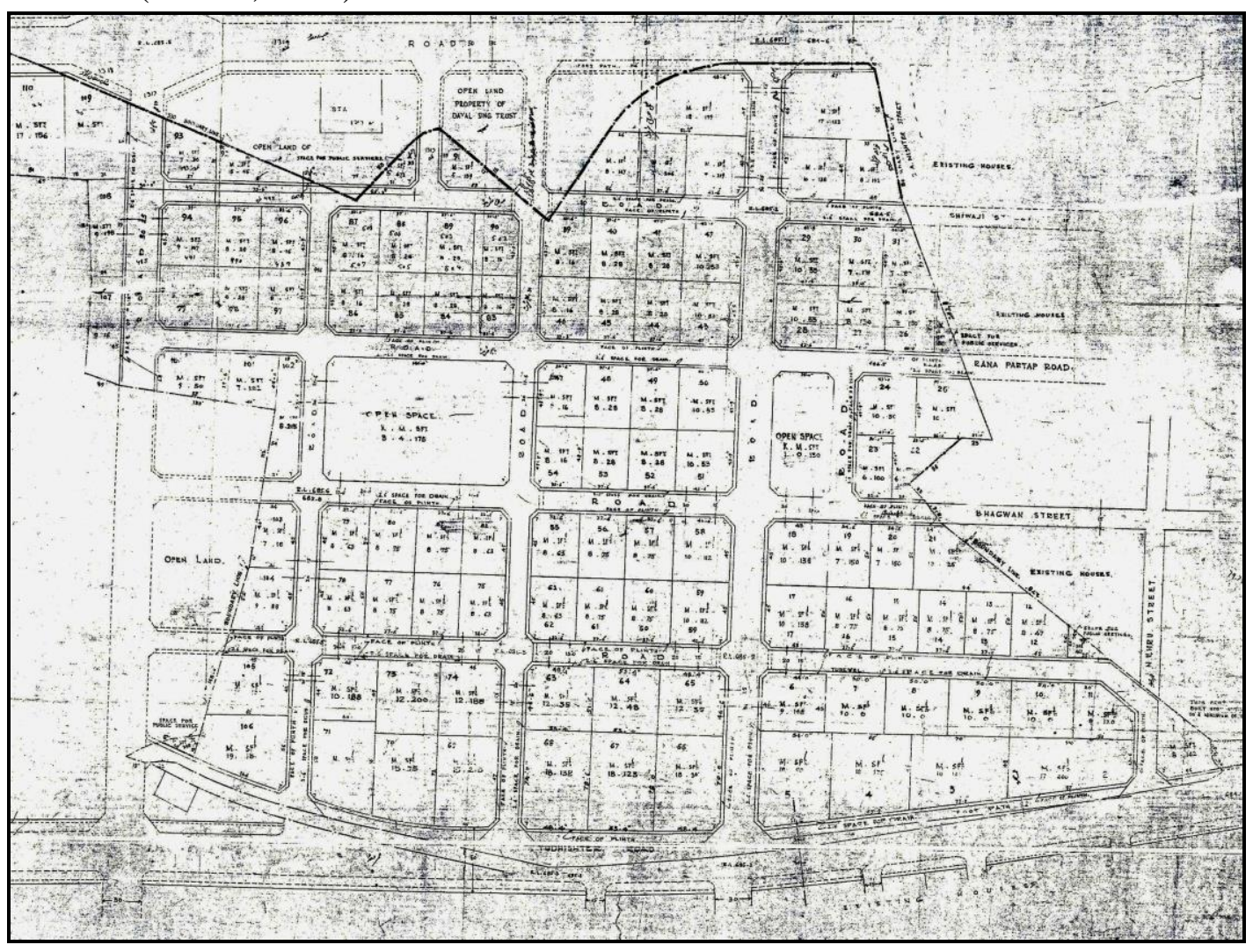

Blow up detail. (3) Krishan Nagar (late colonial period (Planned according to modern planning principles) Source: Punjab Archive ${ }^{8}$ 


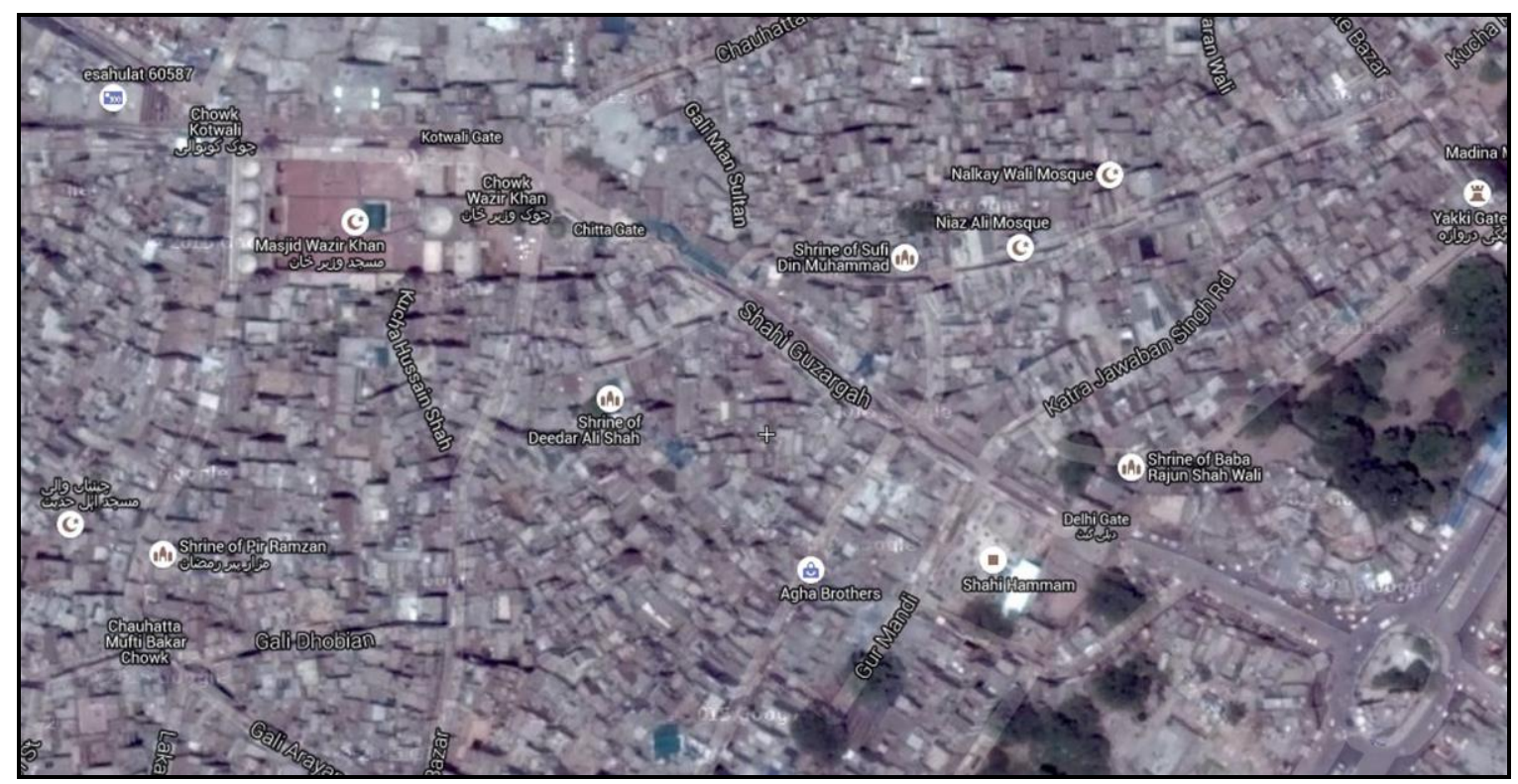

Figure 2 (a). Delhi Gate Guzar, Walled City Lahore.

Source: http://wikimapia.org/\#lang=en\&lat=31.564925\&lon=74.293499\&z=17\&m=h

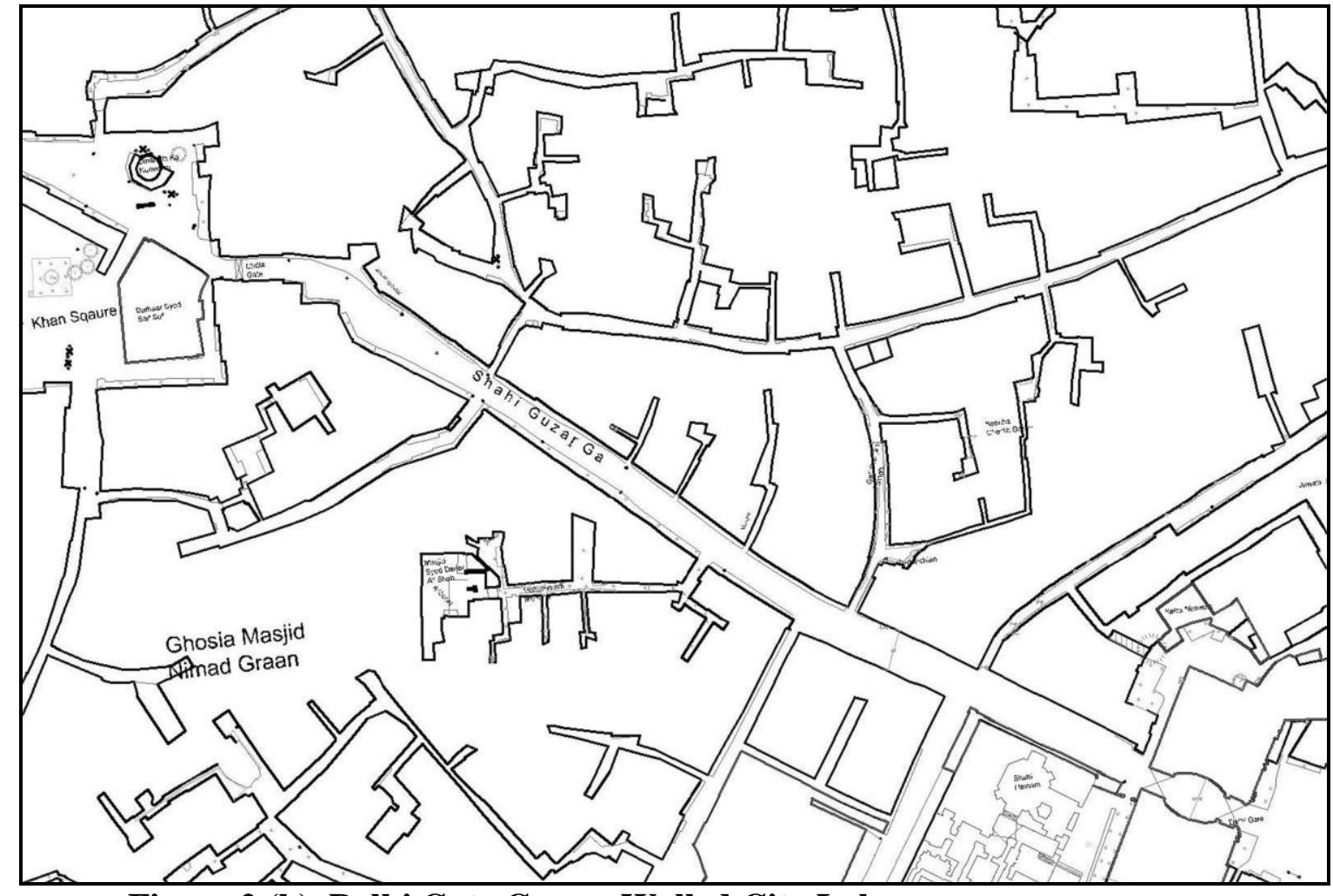

Figure 2 (b). Delhi Gate Guzar, Walled City Lahore.

Source: author and AkCSP (Aga Khan Cultural Service Pakistan). 


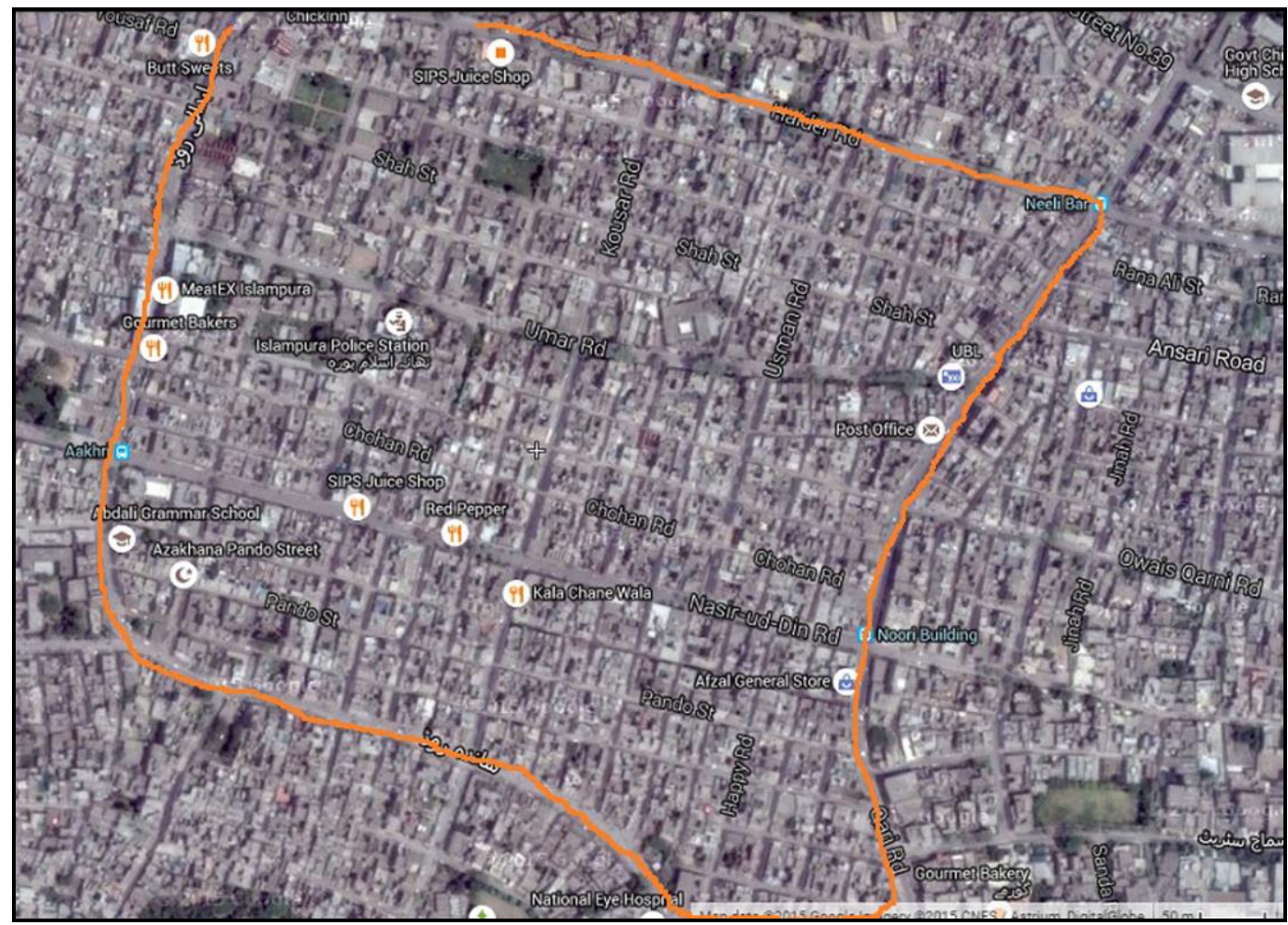

Figure 3 (a). Krishan Nagar, Lahore

Source: http://wikimapia.org/\#lang=en\&lat=31.564925\&lon=74.293499\&z=17\&m=h

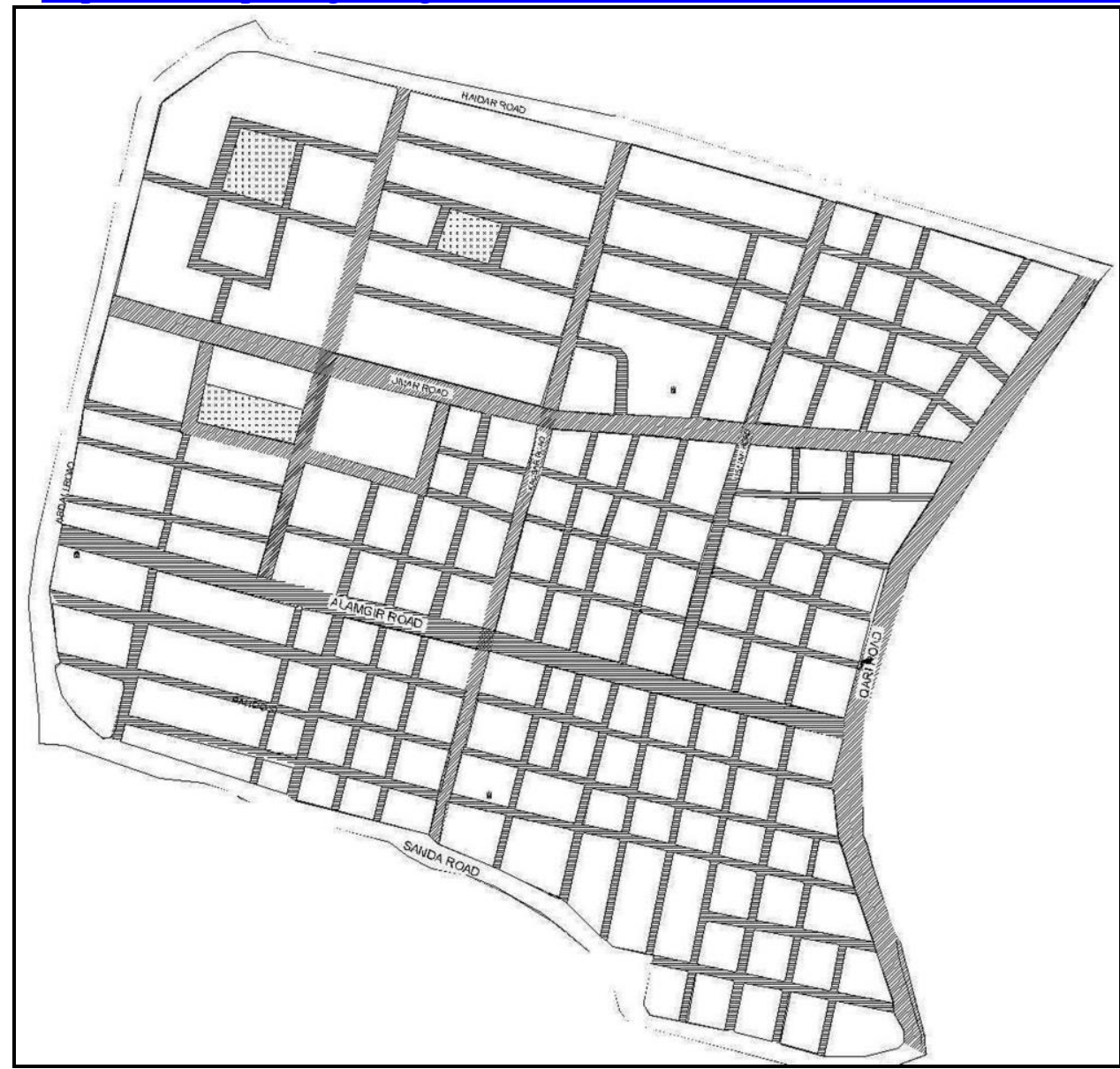


ELK ASIA PACIFIC JOURNAL OF SOCIAL SCIENCES

ISSN 2394-9392 (Online); DOI: 10.16962/EAPJSS/issn.2394-9392/2014; Volume 2 Issue 2 (2016)

Figure 3 (b). Krishan Nagar, Lahore

Source: author and NESPAK (National Engineering Services Pakistan

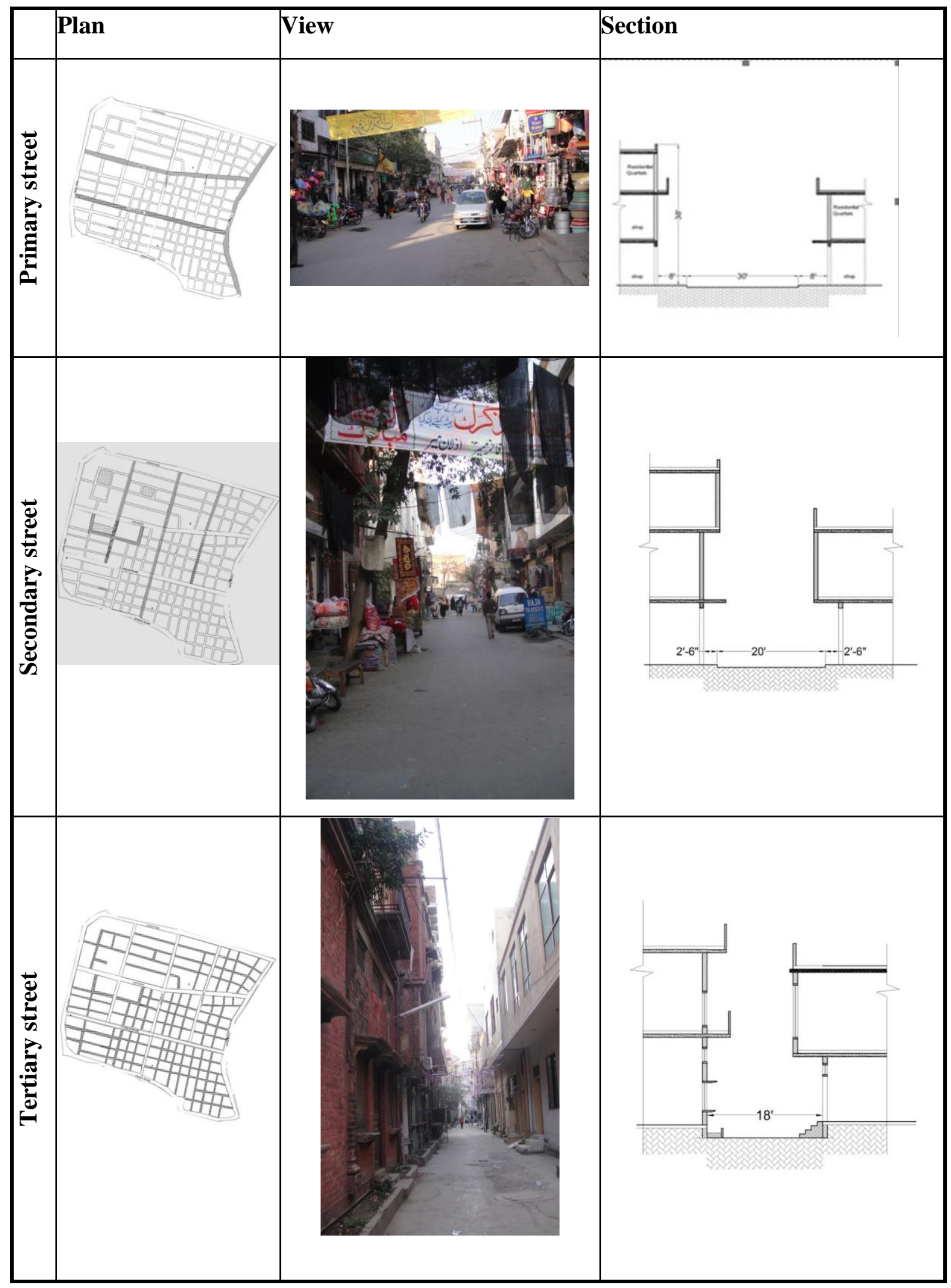


Figure 4 (a). Hierarchy of streets in Krishan Nagar. User can see the other end of street without difficulty and minimum feeling of confinement as layout is orthogonal. Source: author

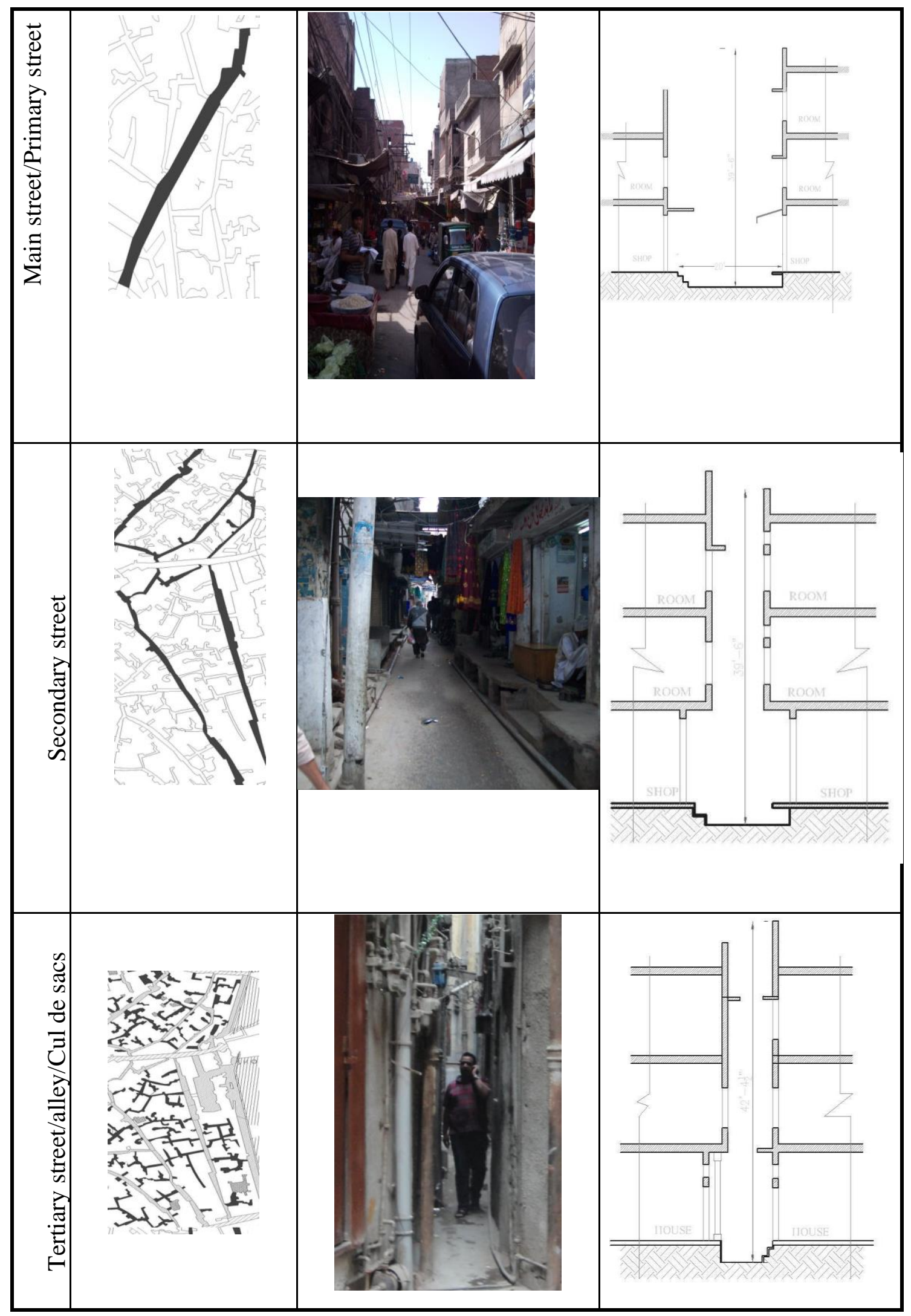


Figure 4 (b). Hierarchy of streets in walled city. Feeling of confinement is maximum with minimum street width 2'-6" and tall flanking buildings. Gaze does not loss in infinity. Even in the primary street though wide enough but never straight. (Yasin, 2011 


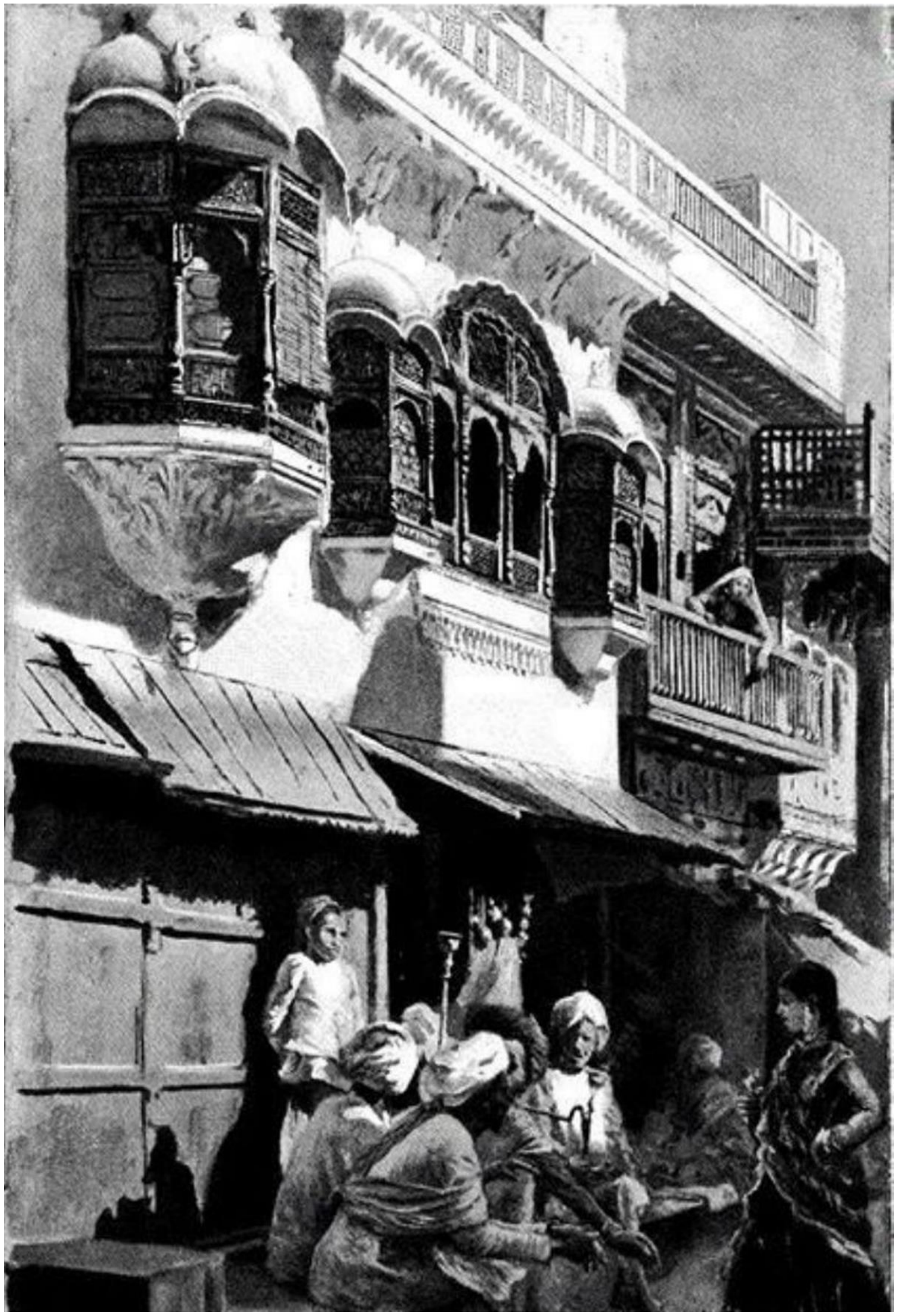

Figure 5 (i). Source: $i^{9}$ (Shahzad, 2015) 


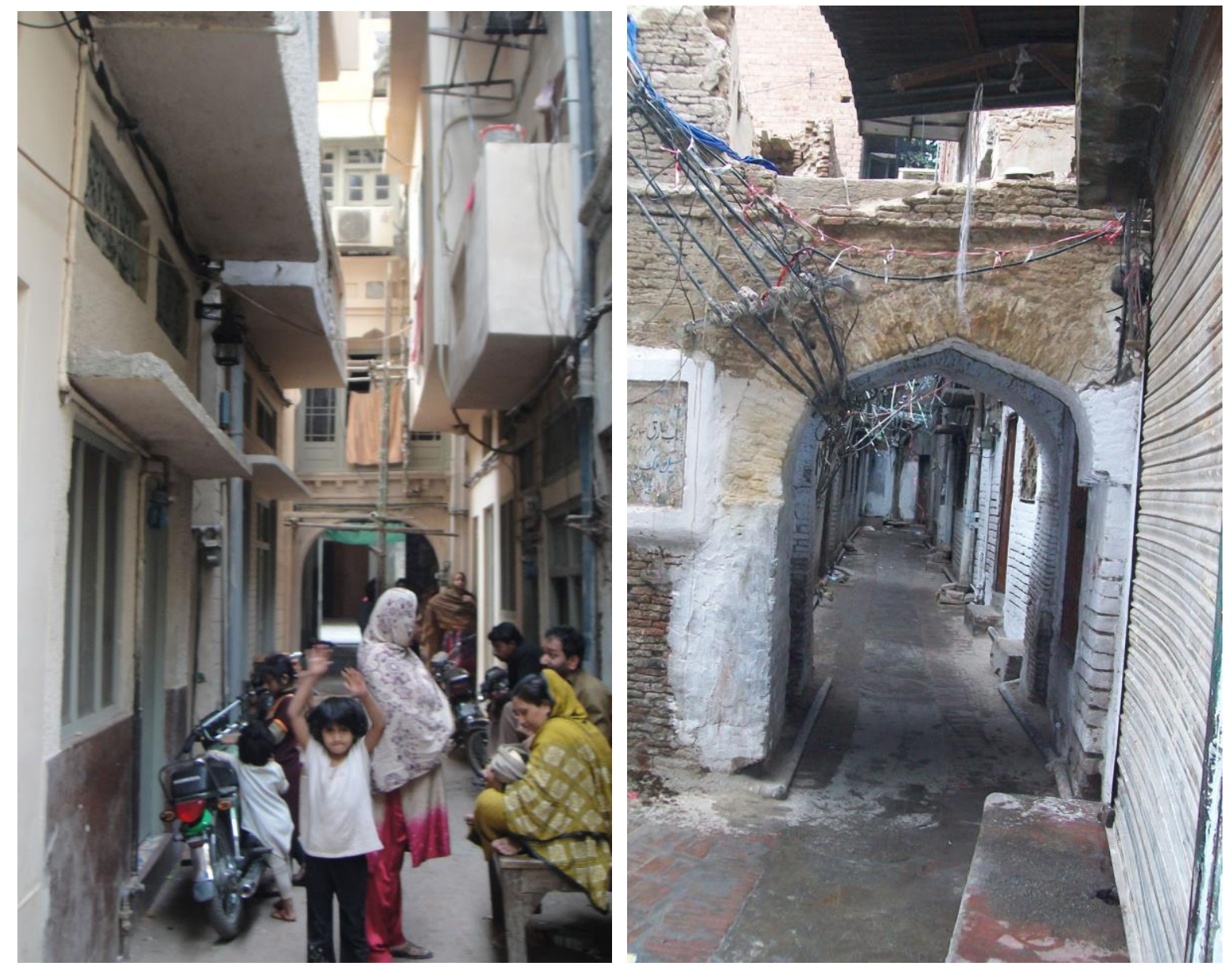

Figure 5 (ii). Source: author

Figure 5 (iii). Source: author

Figure 5(i, ii and iii). Street scenes showing cantilevers, Jharokas, balconies and overhangs and thresholds in the form of arches. Such scenes are rare in NICs.
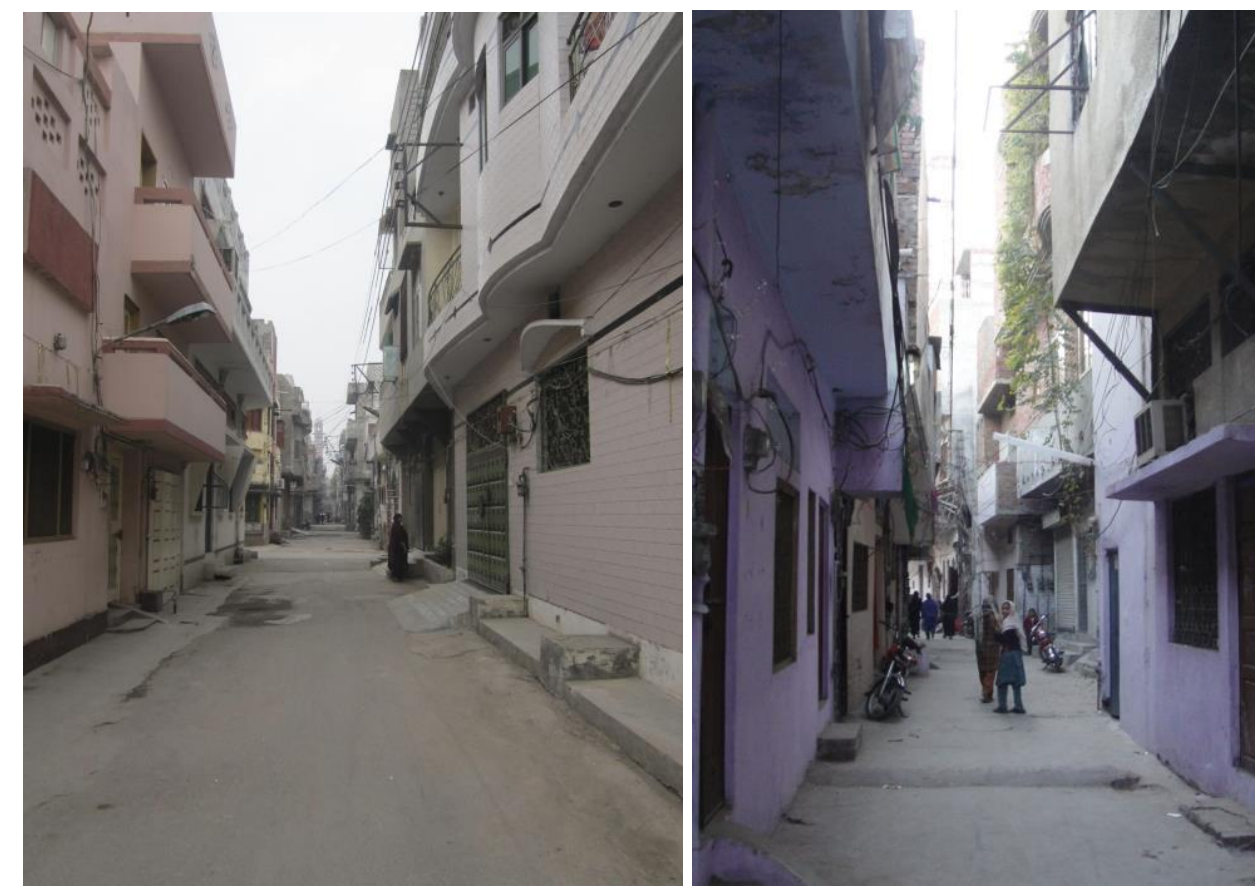

Figure 6(i, ii). Negotiated respect for property line and compromised streetscape at Krishan Nagar: Varying depth of overhangs and entry steps in street space. Source: author 


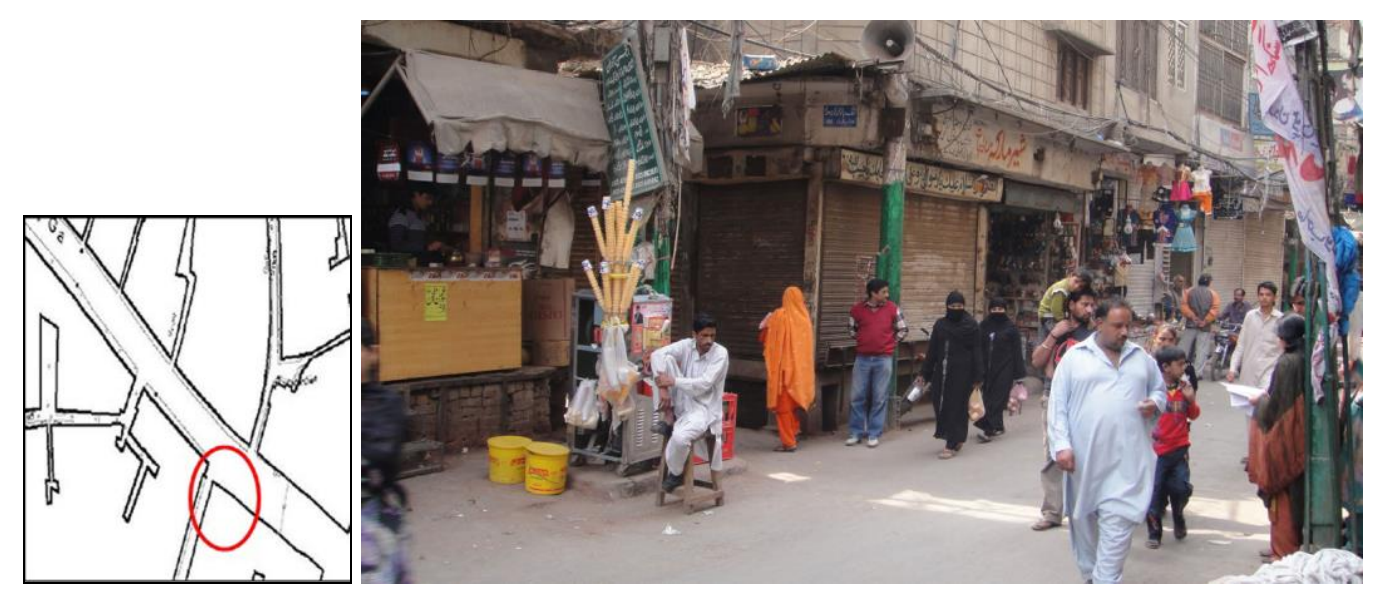

Figure 7. Example of accidental conjunctions, streets leading to Tang bazaar. One side of street is protruded out, making it unaligned. Source: author
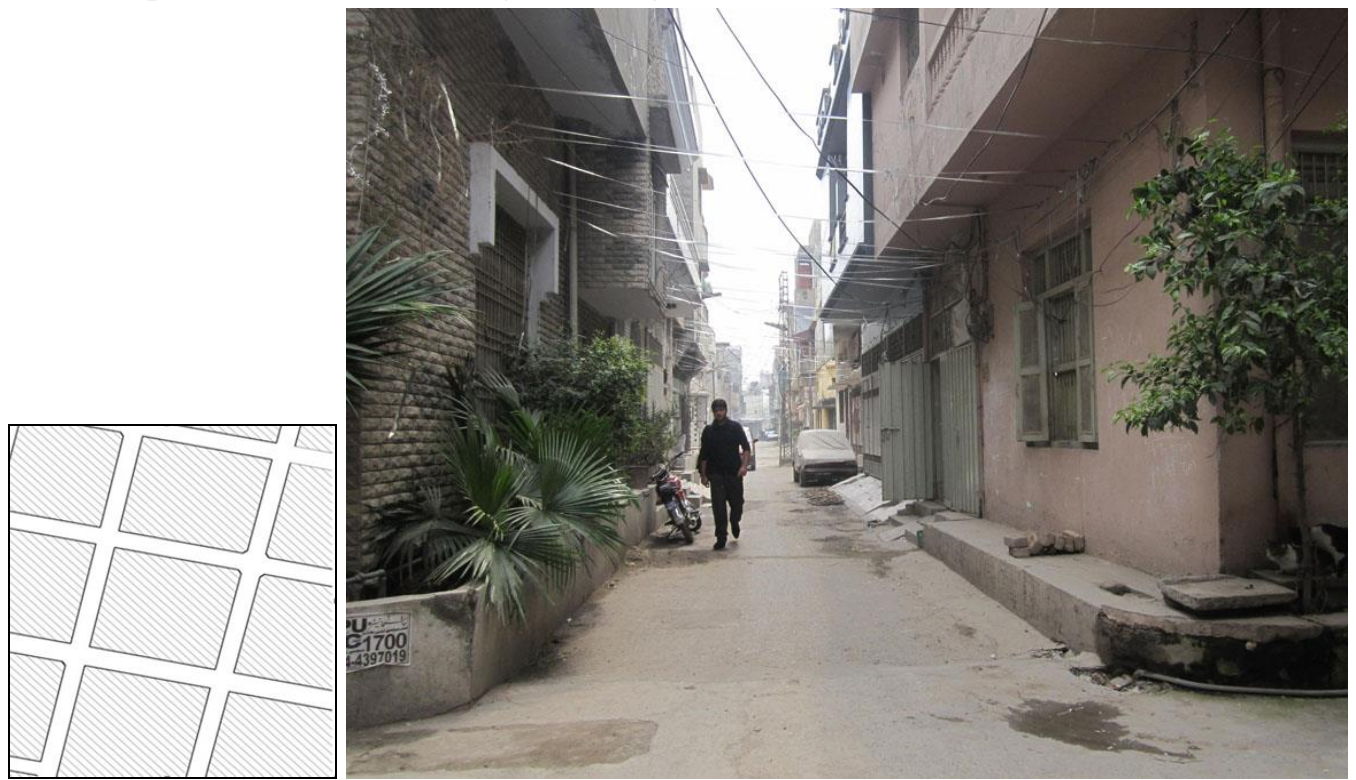

Figure 8. Streets with definite start and end and no accidental conjunctions. Source: author

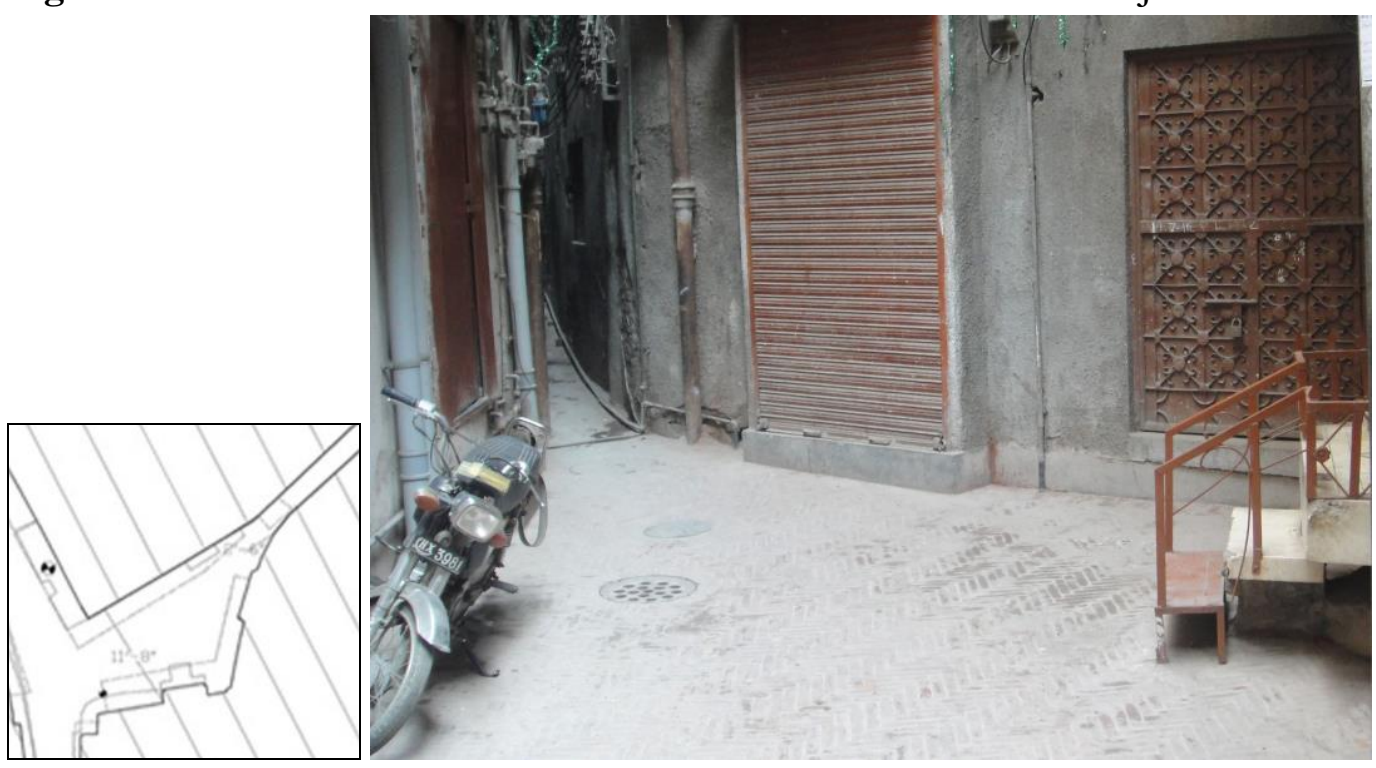


Figure 9. Bulged space in between secondary and tertiary streets. Such spaces are not found in Krishan Nagar. Source: author

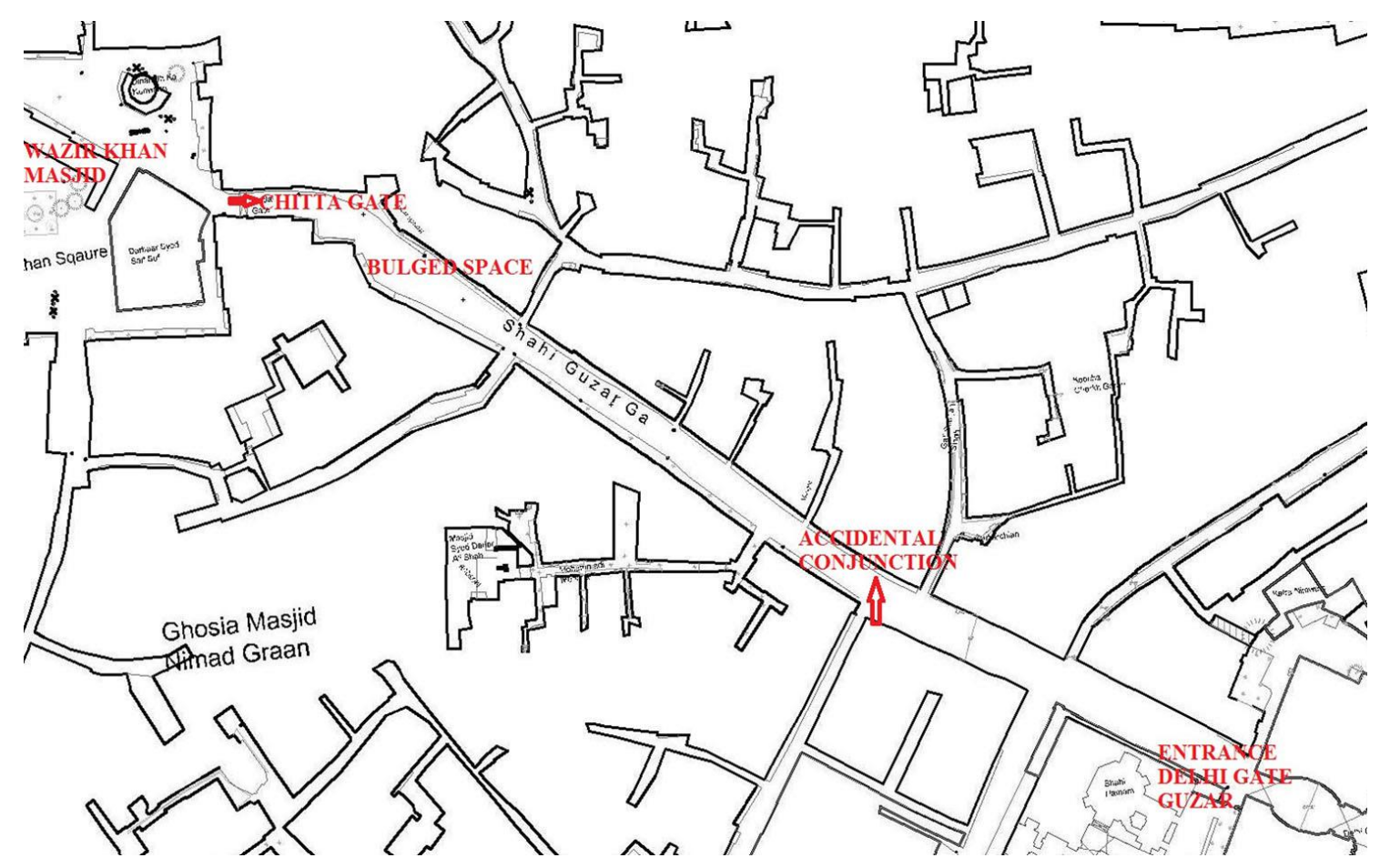

Figure 10. Delightful experience of prosperous bazaar with rich details ends at surprisingly amazed building (Masjid Wazir Khan). Drama accentuated with a bulged space at Chitta gate. Before this passerby can't think of having encounter with mesmerizing building of masjid. Source: author
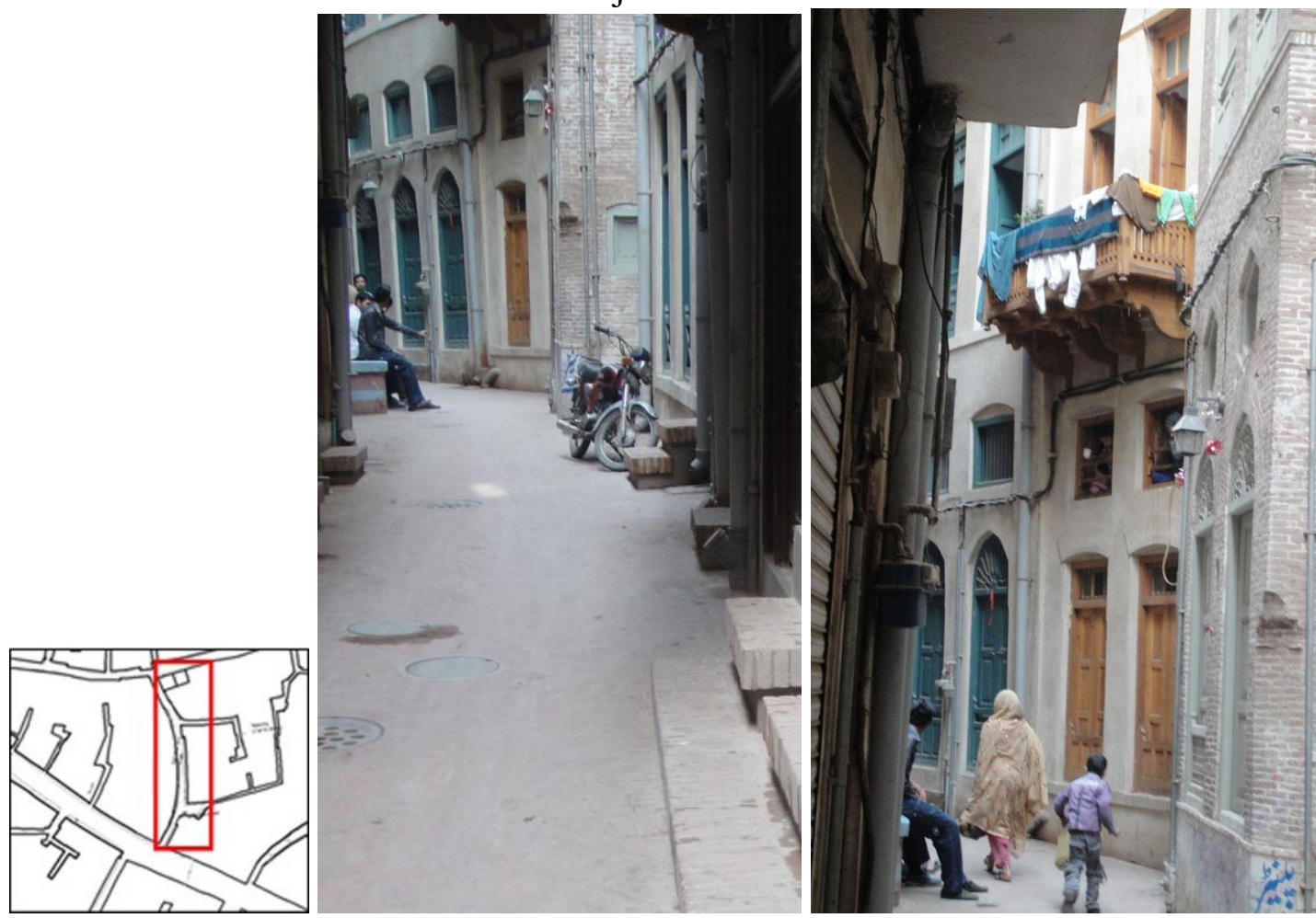
Figure 11. Discovery and exploration at each steps due to convex and concave surfaces provided with deep feeling of enclosure as street is flanked by three storey building with a width of 6'-0". No such setting found in Krishan Nagar.
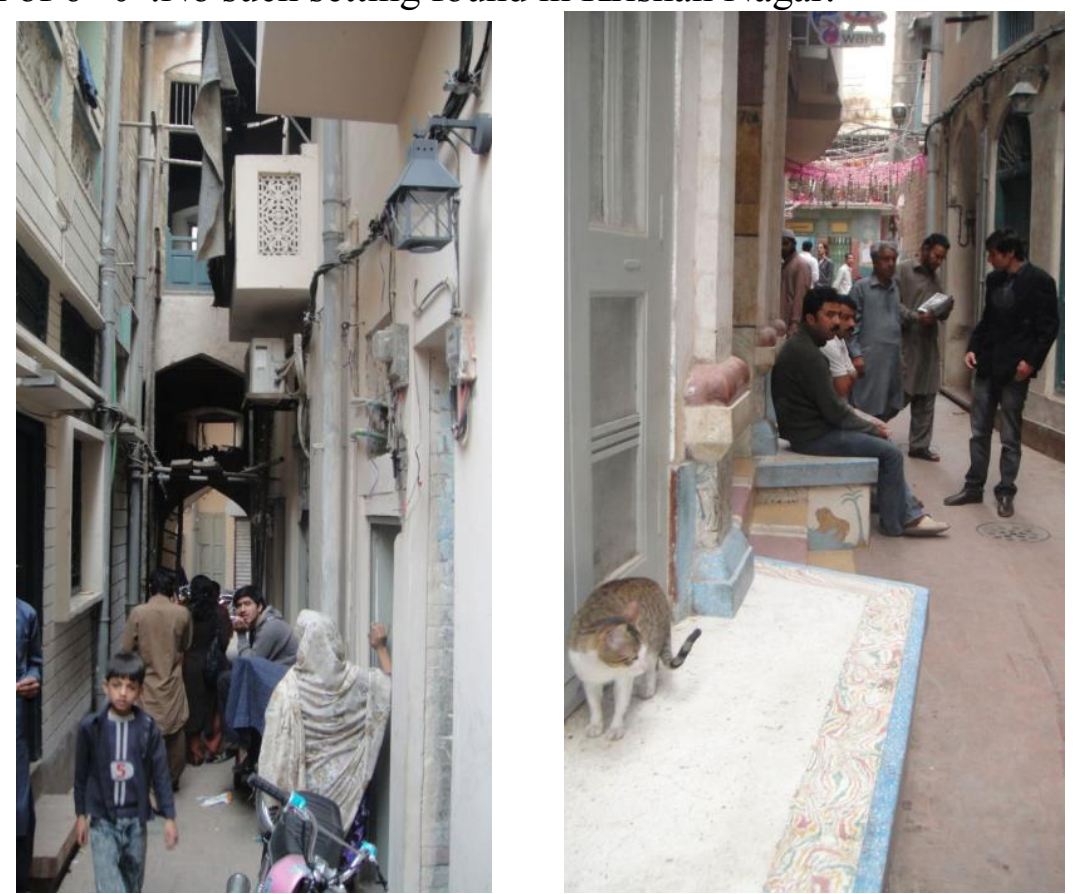

Figure 12. Exaggerated projections and people gossiping under shades sitting on tharras. Source: author 
ELK ASIA PACIFIC JOURNAL OF SOCIAL SCIENCES

ISSN 2394-9392 (Online); DOI: 10.16962/EAPJSS/issn.2394-9392/2014; Volume 2 Issue 2 (2016)

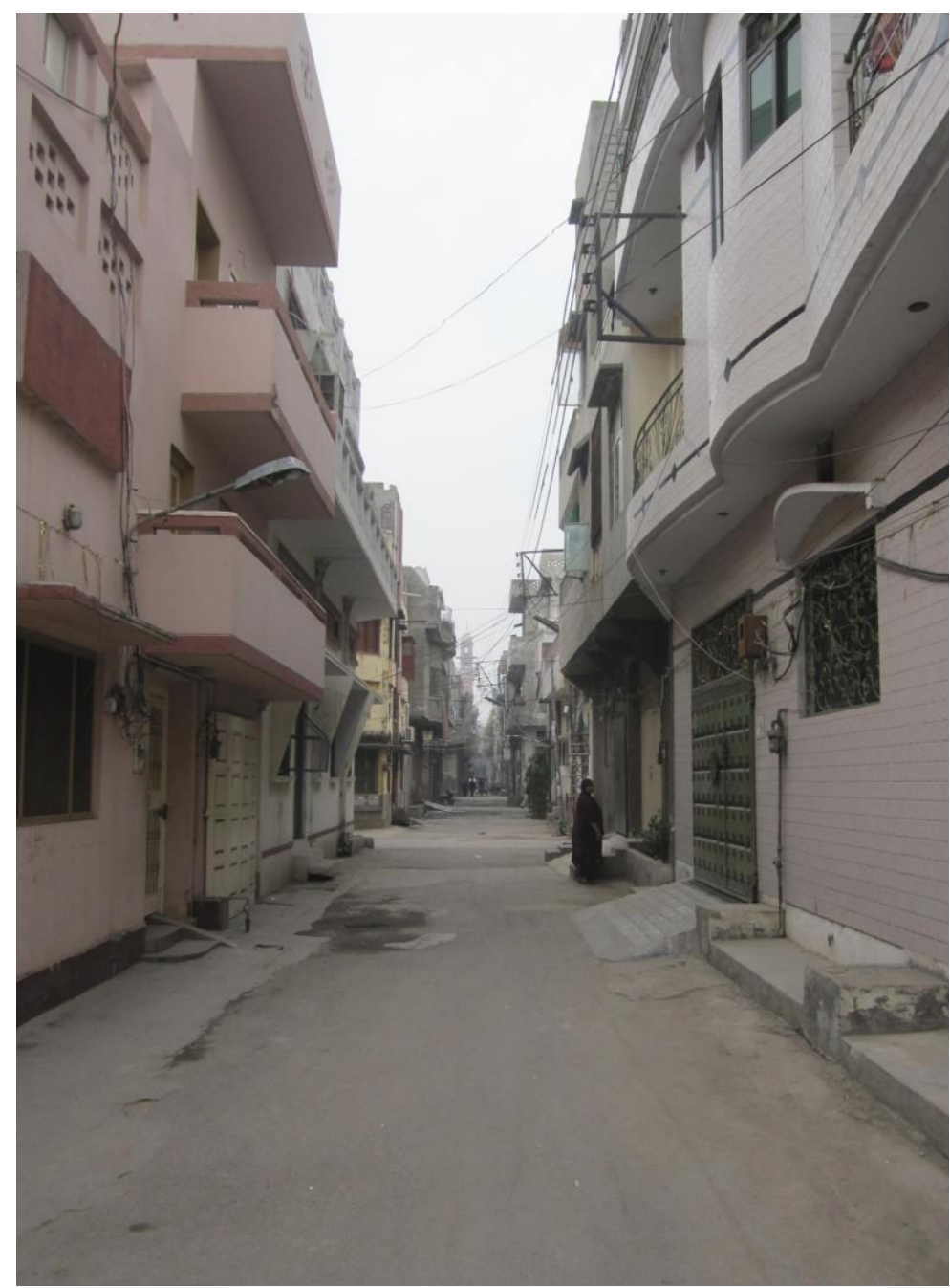

Figure13. Street scenes under restrictions... people tend to extend beyond bye laws. Source: author 
ELK ASIA PACIFIC JOURNAL OF SOCIAL SCIENCES

ISSN 2394-9392 (Online); DOI: 10.16962/EAPJSS/issn.2394-9392/2014; Volume 2 Issue 2 (2016)
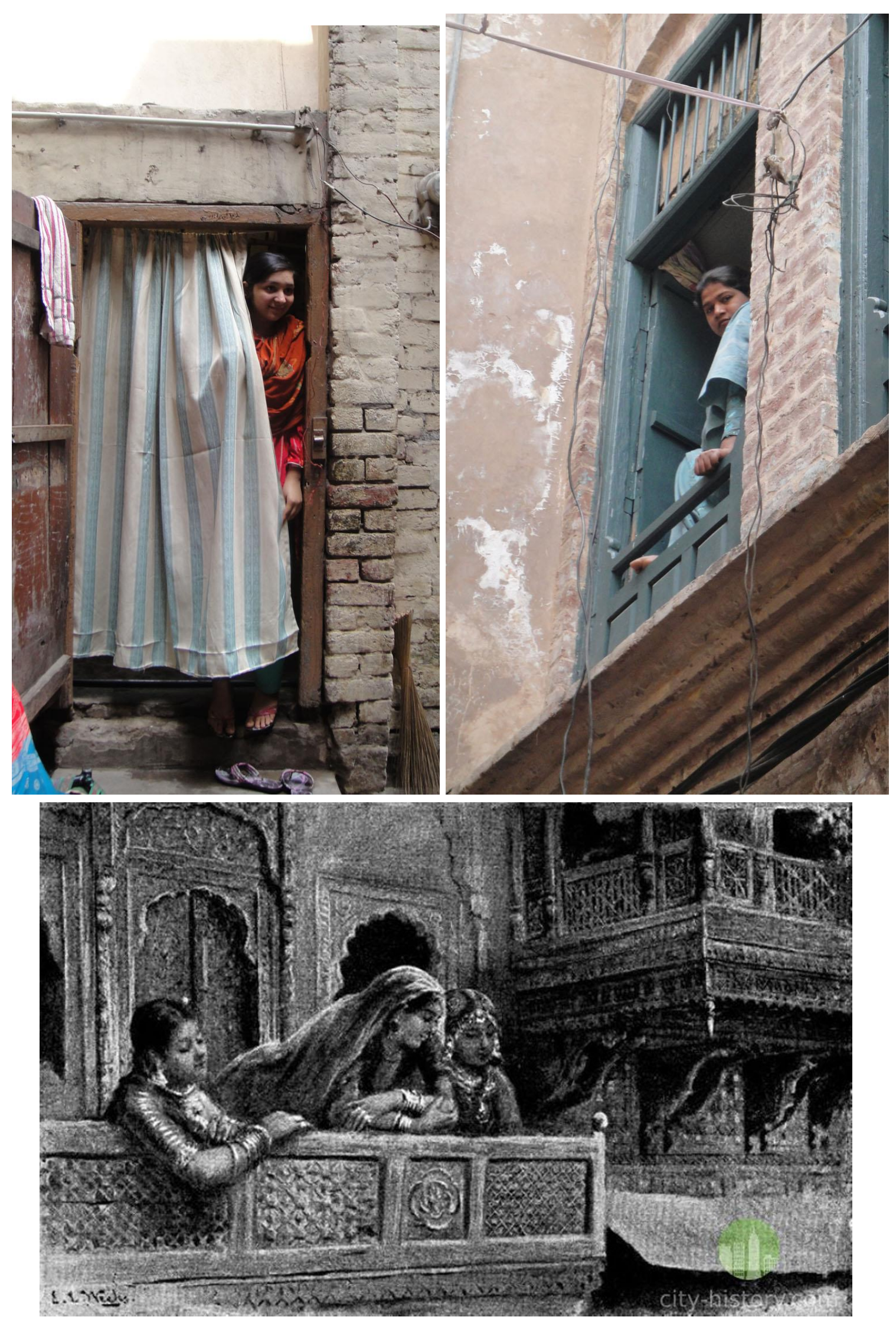
Figure14. Doors and windows opening into the streets represent the simulation of one's being present in street. Women feel free to use windows and balconies as street layout maintain high level of privacy at walled city. Source: author and (Shahzad, 2015)

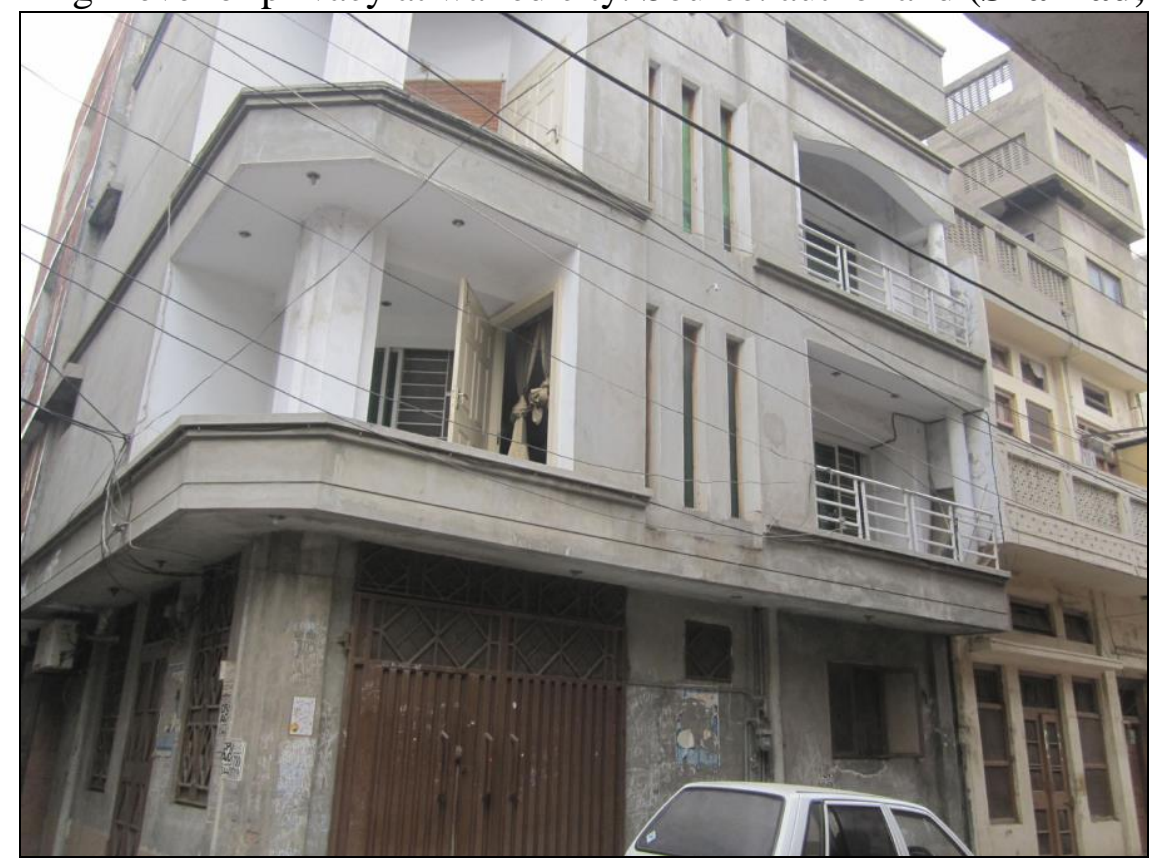

Figure 15. Windows opening into the streets representing the simulation of one's being present in the street. But these windows and balconies are without the presence of women as street layout does not provide privacy at Krishan Nagar
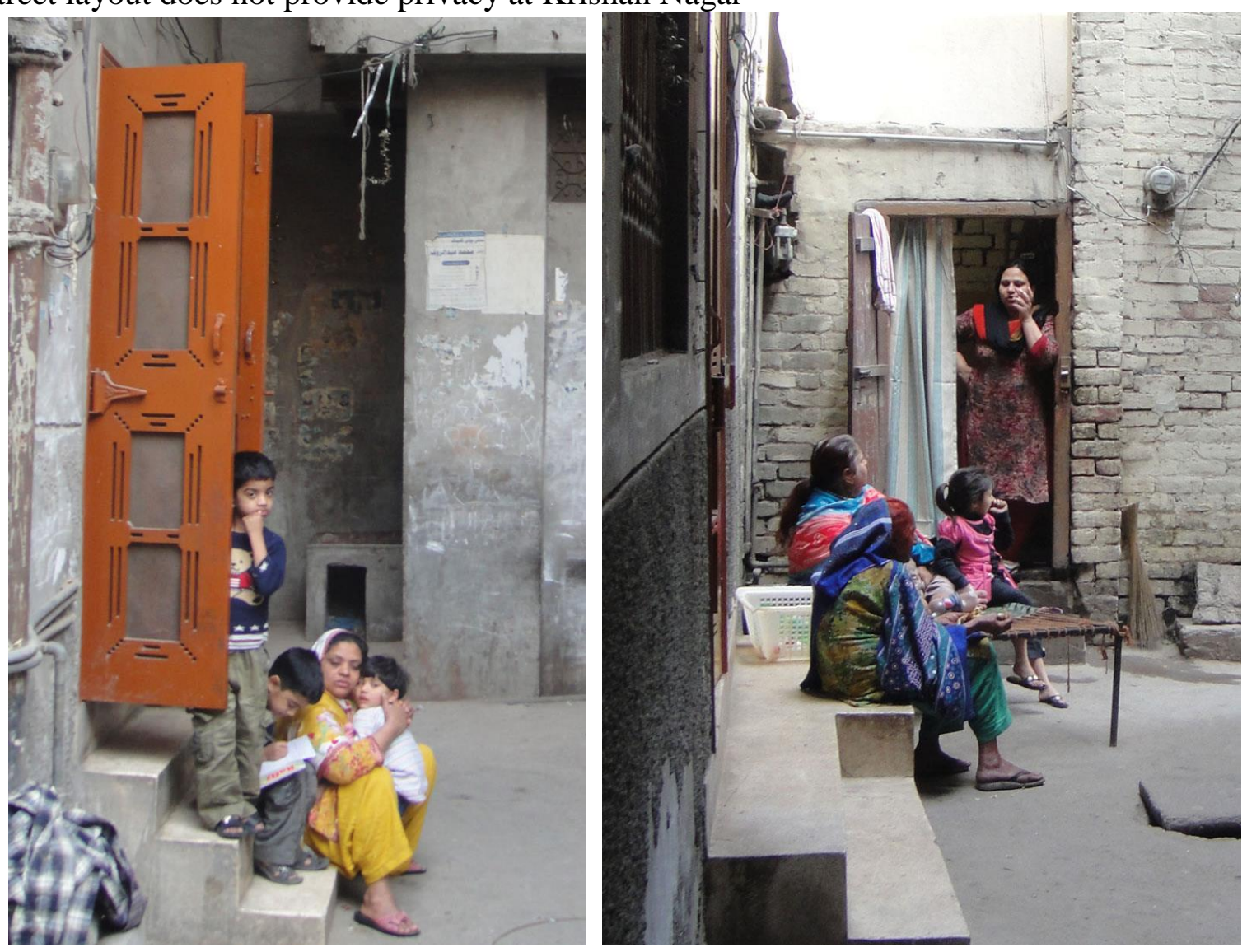
Figure 15. Women sitting and standing free and easy in doorstep, also women sitting on charpai in the street as freely as in the courtyard of house. Source: author

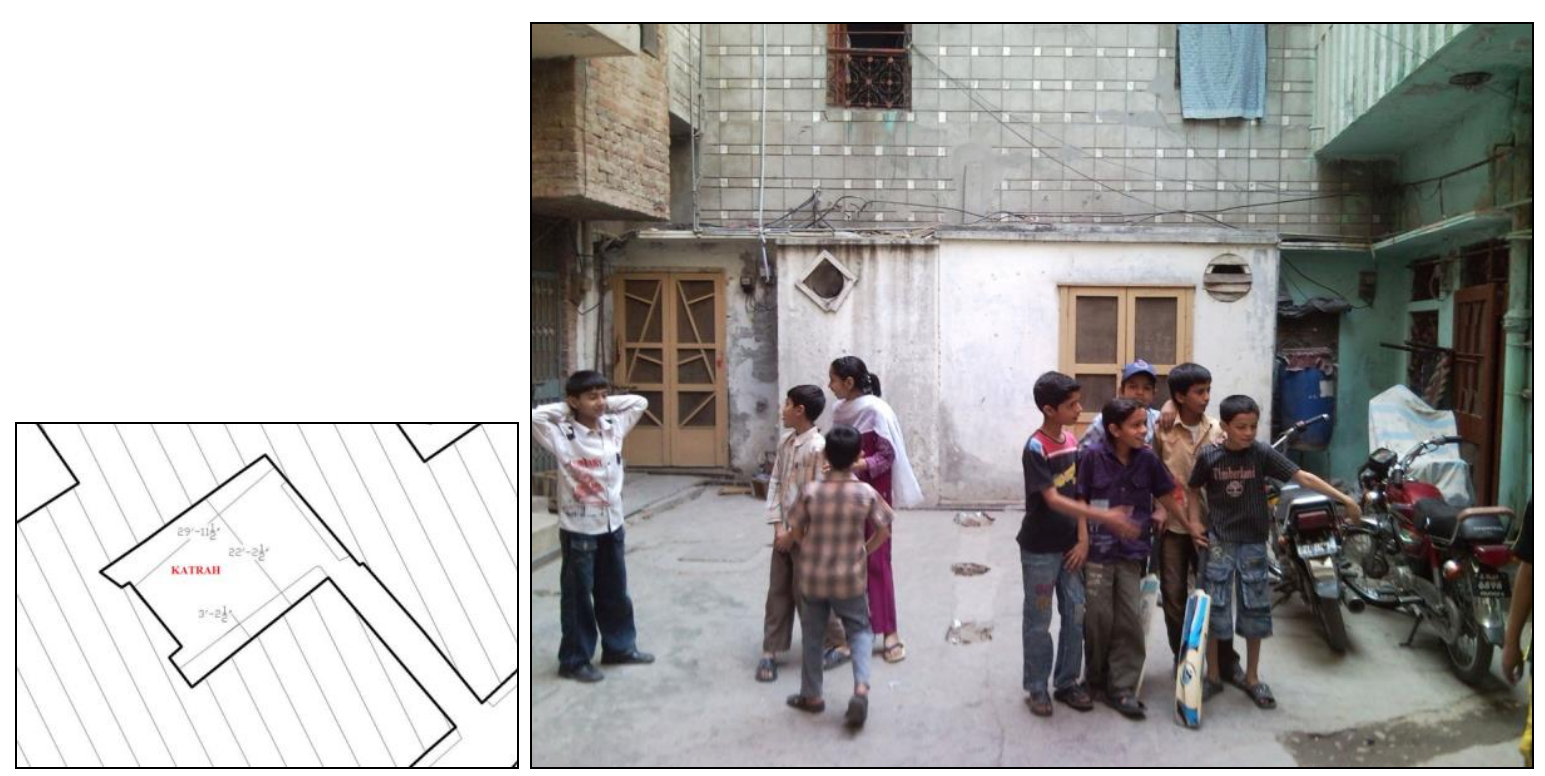

Figure 16.(i) Source: author

Source: (ii) (Yasin, 2011)

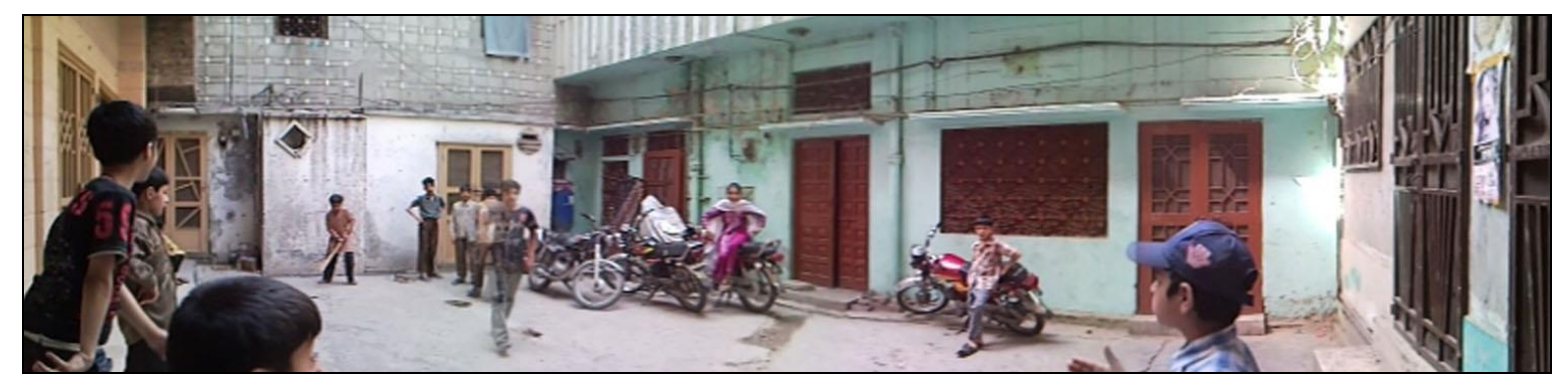

Figure 16. (iii)Katrah, On Sunday children were playing there. Source: author 


\title{
NOTES
}

\begin{abstract}
${ }^{1}$ GOR (government officers residences)
2 It is now part of Islampura neighbourhood. After partition due to repeated protests against Hindu origin names both Sant Nagar and Krishan Nagar were combined and renamed as Islampura neighbourhood.
\end{abstract}

${ }^{3}$ Water pipe used for smoking tobacco. Also called huqqah. Commonly used in subcontinent.

${ }^{4}$ A window projecting outward from wall of a room forming a recess inside.

5 Traditional window opening protruding out in the street.

${ }^{6}$ an enclosed cul de sac surrounded by houses

7 Pakistan Environmental Planning \& Architectural Consultant

8 The Punjab Archives contain one of the biggest collections of historical documents in the subcontinent. This collection, housed in Anarkali's Tomb in the Punjab Secretariat, is estimated to contain 80, 000 books and several million documents

${ }^{9}$ A Fresh Morning, Painting by Edwin Lord Weeks - Lahore c. 1894 From Harper's Monthly Magazine (June-

Nov. 1894) - "Lahore and the Punjab" by Edwin Lord Weeks. 